\title{
Jovellanos y la reivindicación de la arquitectura gótica de Palma
}

\author{
Alejandro Sanz de la Torre *
}

\section{JOVELLANOS EN MALLORCA}

La estancia de Gaspar Melchor de Jovellanos ${ }^{1}$ (Gijón, 1744-Vega, Asturias, 1811) en Mallorca, marcó en sus cartas sobre arquitetura mallorquina escritas en el Castillo de Bellver, un poderoso sentimiento prerromántico y un interés creciente por los grandes edificios góticos de Palma, que significaron el paso de la contenida admiración por aquellos propia de los eruditos y viajeros ilustrados, al declarado entusiasmo ante tales obras propio de los autores del romanticismo. En este aspecto, las cartas de Jovellanos son consideradas un poderoso precedente en la ferviente admiración de los románticos por el gótico mallorquín en particular, y por el estilo gótico en general.

Las disputas políticas entre Jovellanos y Godoy terminaron en la destitución del primero en 1798 como ministro de Gracia y Justicia, y su ulterior destierro en la isla de Mallorca. Jovellanos estuvo confinado en la Cartuja de Valldemosa entre el 18 de abril de 1801 y el 5 de mayo de 1802. Lás filtraciones de algunas cartas suyas provocaron un nuevo traslado y encierro en el Castillo de Bellver, donde estuvo entre el 5 de mayo

Ldo. $\mathrm{H}^{\mathrm{a}}$ del Arte.

La biografía del polígrafo y político gijonés es suficientemente conocida, dada la trascendencia de su obra. Sobre la figura de Jovellarios hay abundante bibliografía, entre otras CEÁN Bermúdez, J.A., Memorias para la vida del Excmo. Sr. D. Gaspar Melchor de Jovellanos... Madrid, Imp. que fue de Fuentenebro, 1814; Nocedal, Cándido, Vida de Jovellanos. Madrid 1865; PE. NaLver SIMO, Patricio, Modernidad tradicional en el pensamiento de Jovellanos. Sevilla, GEHA, 1953; Obras publicadas e inéditas de D. Gaspar Melchor de Jovellanos... Madrid, Atlas, BAE, 1956, vol. LXXXV (Estudio preliminar de Miguel Artola); POLT, John Hermann Richard, Gaspar Melchor de Jovellanos. New York, Twayne pub., 1971; FernÁndez de LA Cigoña, Francisco, Jovellanos, ideología y actitudes religiosas, políticas y económicas. Oviedo, Instituto de Estudios asturianos, 1983. 
de 1802 y el 19 de marzo de 1808 , en que fue liberado tras el motín de Aranjuez (17 de marzo).

Una vez liberado, emprendió un recorrido por la isla, entre el 21 de abril y el 19 de mayo del mismo año, en que embarcó para Barcelona. En estas semanas pudo Jovelianos conocer las principales poblaciones y monumentos de la isla, y contemplar los edificios góticos de Palma, objeto de sus cartas, que hasta entonces sólo conoció a través de los testimonios de sus amigos mallorquines o divisados desde el Castillo.

Su prolongada estancia en el Castillo de Bellver ${ }^{2}$ y el carácter erudito de Jovellanos, exponente de la ideología ilustrada en España, le movieron a escribir una copiosa producción literaria sobre los temas histórico-artísticos de Mallorca. Sus amigos mallorquines le facilitaron libros y manuscritos así como documentos de archivo para sus investigaciones. Jovellanos tomó numerosos datos de las obras de los eruditos e historiadores locales, tales como los padres Cayetano de Mallorca (1707-67), Guillermo Tarrasa (1709-78) y Francisco Talladas (1746-1818), los cronistas Juan Binimelis (1538-1616), Juan Dameto (1554-1633), Vicente Mut (1614-87), Jerónimo Alemany (1693-1753) y Buenaventura Serra (1728-84), los historiadores Jaime Custurer (1657-1715), Francisco Diago (1560-1615), etc., o su contemporáneo y amigo el canónigo José Barberí (1766-1826) ${ }^{3}$.

Junto a estas fuentes, que Jovellanos leyó de manera crítica y censurando sus errores, consultó también numerosos documentos inéditos sacados de los archivos de la isla. Continuando la labor erudita y el rigor científico que José Vargas Ponce (1760-1821) dio a sus Descripciones de las islas Pitiusas y Baleares (Madrid, Vda. de Ibarra, 1787), Jovellanos marcó el camino de los posteriores estudios locales por la vía del estudio riguroso de los archivos mallorquines.

\footnotetext{
Sobre su estancia en Mallorca, sus contactos locales y su producción literaria pueden consultarse varias obras. Ver LlabRÉs QuintanA, Gabriel, "Jovellanos en Mallorca (1801-1808)", en el Boletín de la Sociedad Arqueológica Luliana, t. IV, núm. 136-7. Palma, julio de 1981 y t. IX, 1901-2; GUASP I VICENS, F., "Jovellanos i Barberi", Boletín de la Sociedad Arqueológica Luliana, t. IV. Palma 1891-2; Llabrés BernaL, Juan, "Lugares de la isla visitados por Jovellanos en sus paseos", Boletin de la Sociedad Arqueológica Luliana, t. XXIII. Palma 1930-1; “Amigos y conocidos de Jovellanos en la isla de Mallorca", Boletín de la Sociedad Arqueológica Luliana, t. XXIII. Palma 1930-1 y "Últimos días de Jovellanos en Mallorca", Boletín de la Sociedad Arqueológica Luliana, t. XXIV. Palma 1932-3; САBOT LLOMPART, Juan, Jovellanos confinado en Maliorca. Palma, Imp. Fernando Soler, 1936; SUREDA BLANES, José, Jovellanos en Beliver. Mallorca, Sociedad Arqueológica Luliana, 1947 (también en el Boletín de la sociedad Arqueológica Luliana, ts. XXIX y XXX, 1944-6 y 1947-52); FERnÁNDEZ y GONZÁLEZ, Angel Raimundo, Jovellanos y Mallorca. Palma, Imp. Politécnica, B. March, 1974.

3 Jovellanos, G.M. de, Obras publicadas e inéditas de... ob. cit., vol. LXXXVI, págs. 69130. En su diario n. 12 citó las fuentes consultadas en sus trabajos históricos.
} 
Para consultar todas esas fuentes y mantener su intensa correspondencia con el exterior, dada su prohibición de bajar hasta la ciudad, Jovellanos dependió de la colaboración de varios eruditos y clérigos locales, como José Barberí, Tomás Verí, Francisco Talladas, Luis de Villafranca (1770-1847), etc. También contactó con el notario Miguel Juan de Padrinas, el padre Juan Bautista Capó, el conde de Ayamans, etc., siendo su correo particular su confesor, el padre Ignacio Bas y Bauzá ${ }^{4}$.

\section{SUS CARTAS SOBRE ARQUITECTURA GÓTICA DE PALMA}

De la extensa obra manuscrita realizada por Jovellanos ${ }^{5}$ durante su estancia en el Castillo de Bellver, sus cartas sobre arquitectura mallorquina ${ }^{6}$, dedicadas a los principales edificios góticos palmesanos, son quizá lo más importante, por la gran trascendencia que tuvieron en la reivindicación del estilo gótico con la llegada del romanticismo y la difusión del gusto por tal estilo. El objeto de tales cartas, fue facilitar a Juan Agustín Ceán Bermúdez (1749-1829) ${ }^{7}$ materal par las adiciones al libro de Eugenio Llaguno Noticias de los Arquitectos y Arquitectura de España..., en lo que estaba ocupado.

Antes de su paso por Mallorca, los juicios de Jovellanos sobre el estilo gótico fueron similares a los de los demás eruditos ilustrados, de admiración, aunque dentro de los rígidos criterios neoclásicos. Esta actitud quedó bien patente en obras anteriores suyas, como en el Elogio de las Bellas Artes $(1781)^{8}$ o en el Elogio de don Ventura Rodríguez (1788) ${ }^{9}$.

4 Sureda Blanes, José, Jovellanos en Bellver... ob. cit., págs. 83-4. El autor cita también las principales obras que consultó y copió Jovellanos.

5 La recopilación más completa de los escritos de Jovellanos durante su estancia en Mallorca es la de Fernández y González, Angel Raimundo, Jovellanos y Mallorca, ob. cit., págs. 183-205. También puede verse el «Indice cronológico de las obras de Jovellanos", en JoveLLANOS, G.M. de, Obras públicas e inéditas de... ob. cit.,, 1956, vol. LXXXVII.

6 Existen varias recopilaciones de los escritos de Jovellanos. Hemos utilizado la más reciente: Obras publicadas e inéditas de D. Gaspar Melchor de Jovellanos... Madrid, Atlas, 1952 $63, V$ vols. Son los vols. XLVI, L, LXXXV, LXXXVI y LXXXVII de la BAE.

7 Así lo reconoce el propio Ceán: «sabía muy bien el señor don Gaspar que yo me ocupaba en adicionar las Noticias de los Arquitectos y Arquitectura de España, que había trabajado el señor don Eugenio Llaguno, y me había dejado por su muerte; y deseoso de complacerme se tomó el trabajo de formar las descripciones artísticas del castillo de Bellver, en que estaba encerrado, de sus vistas, de la Lonja y de otros edificios de Palma con diseños y apéndices, que componen cinco volúmenes, y una carta sobre la arquitecture inglesa y la llamada gótica..." CeÁn Bermúdez, Juan Agustín, Memorias para la vida... ob. cit., pág. 90.

\& Publicada con el titulo de Historia y destino de las Bellas Artes en España. (Elogio de las Bellas Artes). Barcelona, J. Verdaguer, 1840. Se refería a la arquitectura gótica en términos elogiosos, alabando su grandeza, el lujo de sus adornos y la delicadeza de su trakajo. «Pero sobre todo es admirable en los templos. iQué suntuosidad! iQué delicadeza! iQué seriedad tan 
Su prisión en el Castillo de Bellver desde 1802 y su contacto con la arquitectura gótica de Palma, reforzaron su admiración hacia estas obras. En su estudio Sobre la arquitectura inglesa y la llamada gótica (1805) ${ }^{10}$, mantuvo la originalidad de la arquitectura gótica, al no ser simple copia de la naturaleza y poseer contenidos de índole espiritual, primando lo imaginativo sobre lo real. Sin embargo, consideró siempre superior desde el punto de vista estético el arte clásico, señalando cómo los ingleses, tan amantes del gótico, «no han desconocido el mérito superior de la bella y majestuosa arquitectura griega» ${ }^{11}$.

Sus estudios sobre los edificios góticos de Palma se iniciaron con sus Memorias del Castillo de Bellver. Descripción Panorámica (1805) ${ }^{12}$. El gijonés describió entusiasmado algunos de los principales edificios góticos, como la Catedral, la Lonja, los conventos de Sto. Domingo y S. Francisco, el Palacio de la Almudaina, el conjunto de Porto- $\mathrm{Pi}^{13}$, las murallas, etc.

augusta no admiramos todavía en las célebres iglesias de Burgos, de Toledo, de León y Sevilla! Parece que el ingenio de aquellos artistas apuraba todo su saber para idear una morada digna del Ser Supremo. Al entrar en estos templos, el hombre se siente penetrado de una profunda y silenciosa reverencia, que apoderándose de su espiritu, le dispone suavemente a la contemplación de las verdades eternas.

Pero examinad las partes de estos inmensos edificios a la luz de los principios del arte. iQué multitud tan prodigiosa de delgadas columnas, reunidas entre si para formar los apoyos de las altas bóvedas! iQué profusión, qué lujo en los adornos! iQué menudencia, que nimiedad en el trabajo! iQué laberinto tan intrincado de capiteles, torrecillas, pirámides, templetes, derramados sin orden y sin necesidad por todas partes del templo! iQué desproporción tan visible entre su anchura y su elevación, entre las partes sostenidas y las que sostienen, entre lo principal y lo accesorio!, en Jovellanos, G.M. de, Obras publicadas e inéditas de... ob., cit., 1963, vol. XLVI, pág. 351 .

9 Jovellanos, G.M. de, Elogio de d. Ventura Rodríguez. Madrid, Imp. vda. de Ibarra, 1790. En esta obra continúa en su admiración hacia la arquitectura gótica, aunque considerándola de origen oriental (ultramarino), y trasmitida a Europa por los cruzados. Las catedrales para él recordaban a los castillos de ultramar. Esta idea de su origen oriental, contradiciendo su opinión anterior del Elogio de las Bellas Artes donde la suponía de origen tudesco (germánico), ya aparece en sus Intormes sobre la publicación de los monumentos de Granada y Córdoba (1786).

to Publicada por primera vez en SOMOzA DE MONTsoniu, Julio, Escritos inéditos de Jovellanos... Barcelona, Tip. Arte y Letras, 1891. Es el vol. IV de las Obras escogidas de D. Gaspar Melchor de Jovellanos. Barcelona, Daniel Cortezo y Cia., 1884-6, III vols. En esta obra señala cómo los ingleses apreciaron antes que ningún pueblo el mérito de la arquitectura gótica (aún reconociendo el mérito superior de la griega), y destaca la protección de tal patrimonio, alabando "el gran cuidado con que buscan y reparan e imitan sus monumentos, y tratan de perpetuarios por medio del grabado". Jovellanos, G.M. de, Obras publicadas e inéditas de... ob. cit., vol. LXXXVII, pág. 377 .

"Jovellanos, G.M. de, lbidem.

12 Publicada por primera vez por BOVER de Rosselló, J. M. ${ }^{a}$, Diccionario histórico-geográfico-estadistico de las Islas Baleares. Palma, Imp. de Felipe Guasp, 1843, págs. XXXIX-LXXXVI.

${ }_{13}$ El secretario de Jovellanos, Manuel Martínez Marina y el escultor Francisco Tomás, dibujaron unas vistas de las torres medievales de Porto-Pi y Pelaires, del Castillo de $\mathrm{S}$. Carlos y del oratorio de S. Nicolás, para completar los dibujos del Castillo de Bellver. Publicados en FERNÁNDEZ Y GonzÁLEZ A.R., Jovellanos y Mallorca, ob. cit. 
Lamentó la degradación de tales monumentos, influyendo en los autores románticos, muy sensibilizados ante la ruina del patrimonio monumental.

Sus Memorias del Castillo de Bellver. Descripción histórico-artística $(1805){ }^{14}$ son las que más influyeron en los escritores románticos. En esta carta, Jovellanos hizo la descripción histórico-artística del Castillo de Bellver, elogiando la gracia y belleza de arcos y bóvedas góticas. Estudió la naturaleza de los alrededores, haciendo observaciones de aquella. Jovellanos se dejó llevar por una vena prerromántica, comentando la belleza del paisaje circundante o mostrándose lleno de nostalgia y sentimentalismo, al hablar de su cautiverio, evocando con idealización los fantasmas de sus ocupantes medievales.

Al igual que en la carta anterior, criticó el descuido del patrimonio monumental viendo la dejadez del edificio ${ }^{15}$; Jovellanos insistió en la necesidad de preservar al menos la memoria de estos edificios testigos de las pasadas glorias, a través del dibujo y del grabado ${ }^{16}$.

14 Publicadas por vez primera en la Colección de varias obras en prosa y verso del Excmo. Sr. D. Gaspar Melchor de Jovellanos. Adicionada con algunas notas por D. Ramón María Cañedo. Madrid, Imp. León Amarita, 1830-2, vol. V.

15 "Pero el tiempo, que disipó aquellos objetos, va consumiendo ahora con diente roedor hasta las duras piedras de este edificio, cuya decadencia ofrece al observador otras reflexiones de muy diferente naturaleza... la verdadera flaqueza de esta obra no se esconde a la observación de su interior. El dice que los muros van poco a poco perdiendo su aplomo, pues se los ve acá y allá desprendidos, y aún separados del labio de las bóvedas, sin duda, a lo que yo judgo, a efectos del empuje de los garitones... Y si a esto se añade el lento estrago que van haciendo en las bóvedas las aguas transcoladas desde la plataforma, que ya gotean en abundancia sobre las habitaciones y galerias, y las filtradas del aljibe, que atacan sus cimientos, fácil es de inferir que el hado de ruina y mortalidad viene con paso acelerado sobre esta fortaleza”. Jovel LANOS, G.M. de, Obras publicadas e inéditas de... ob. cit., vol. XLVI, págs. 396-7.

16 Sería lástima que una mano diestra no extienda por medio del dibujo y el grabado su noticia, preservándole de la ruina que amenaza, no sólo a sus piedras sino también a su memoria. Yo lo he procurado, haciendo formar un bosquejo de su planta y alzada, que aunque imperfecto, servirá para dar a usted y conservar alguna idea de sus ya afeadas bellezas". Jo velLaNos, G.M. de, Obras publicadas e inéditas de... ob. cit., vol. XLVI, pág. 398.

Estos dibujos del alzado y corte del Castillo de Bellver, planta, perfil topográfico del monte y Castillo de Bellver y detalles de arcos, columnas, capiteles, puertas y verjas del mismo, están publicados por Fernández González, A.R., Jovellanos y Mallorca. Ob. cit. Sobre la autoría de tales dibujos señala Barón Thaidigsmann: «tales dibujos fueron realizados por Manuel Martínez Marina, eventualmente auxiliado por el escultor palmesano Francisco Tomás, que también hizo para Jovellanos planos y secciones de la Catedral de Palma. En todos ellos, además de procurarse la mayor exactitud en el más pequeño detalle, pues se trataba de dar una perfecta idea de los monumentos a Ceán Bermúdez, se especifica la escala, en pies castellanos, salvo en el perfil topográfico del castillo, donde se señala la distancia plarimétrica al mar y su altitud sobre él. Se observa, ante estos dibujos, que Jovellanos, ...huye de todo pintoresquismo como si reservase éste para la descripción escrita". Barón Thaidigsmann, Javier, ldeas de Jovellanos sobre arquitectura (arquitectura altomedieval). Oviedo, Servicio de Publicaciones del Principado de Asturias, 1985, págs. 39-40. Manuel Martínez Marina era secretario de Jovellanos; su her- 
Estas memorias del Castillo de Bellver se completaron con las Memorias del Castillo de Bellver. Apéndice primero (1805) ${ }^{17}$. En este breve apéndice, Jovellanos narró la historia del edificio en base al estudio de las crónicas de Dameto y Mut y de los documentos de su fábrica, extrayendo numerosos datos de éstos.

En su Descripción histórico-artística de la Lonja de Palma (1806-8) ${ }^{18}$, Jovellanos narró su historia, dejando sus comentarios artísticos para su Descripción Panorámica desde el Castillo de Bellver. Estudió los documentos de su fábrica cotejándolos con las crónicas de Binimelis, Dameto y Mut, recordando los pleitos de Guillermo Sagrera con el Colegio de Mercaderes, cliente de la obra. En esta carta revivió Jovellanos la riqueza del comercio mallorquín durante la Edad Media, lamentando su decadencia tras el descubrimiento de América y la apertura de la ruta portuguesa de las especias. Esta descripción de la Lonja se completó con las Notas y documentos relativos a la descripción de la Lonja de Palma (1806-8) ${ }^{19}$.

En su Memoria sobre las fábricas de los conventos de Sto. Domingo y S. Francisco de Palma $(1806-8)^{20}$, Jovellanos hizo la descripción histórico-artística de los dos conventos más importantes de Palma. Del convento de dominicos aportó numerosos datos históricos, siguiendo las crónicas del convento y las obras de Diego, Dameto y Serra. Sobre la historia del convento de S. Francisco siguió a Dameto, al padre Cayetano de Mallorca y al cronista franciscano Jaime Soliveretas (1687-1757). Junto a la narración histórica, elogió la arquitectura gótica de ambas iglesias y conventos. Su conocimiento del esplendor político y comercial del Reino de Mallorca, y su admiración hacia la riqueza artística de los edificios góticos de Palma, cualitativa y cuantitativamente superiores a los de otros

mano Juan era el arquitecto propuesto por Jovellanos para las obras de la Cartuja de Valldemosa. Ver Sureda Blanes, José, Jovellanos en Bellver. Ob. cit., pág. 72.

17 Publicado por vez primera en Jovellanos, G.M. de, Memorias históricas sobre el Castillo de Bellver en la isla de Mallorca. Palma, Imp. Miguel Domingo, 1813.

18 Publicada por primera vez en Jovellanos, G.M. de, Carta histórico critica sobre el edificio de la Lonja de Mallorca. Palma, Imp. de Brusi, 1812 (reeditada en Palma, Imp. de Juan Guasp y Pascual, 1835). El libro se publicó a expensas del Real Consulado del Mar, y se completó con cuatro calcografías de Francisco Jordán sobre dibujos del arquitecto Isidro Velázquez, realizadas en Palma en 1813. Estas visitas corresponden a las fachadas principal (este) y norte, la planta y el corte por largo del interior de la Lonja. Ver SANZ DE LA TORRE, Alejandro, "La arquitectura de Palma de Mallorca en el grabado ilustrado (siglos XvIII y $\mathrm{x} \mid \mathrm{X}$ )", Academia, n. ${ }^{\circ} 73$. Madrid 1991, págs. 221-5. Los dibujos son de gran rigor arqueológico.

19 Publicados por vez primera en las Obras publicadas e inéditas de D. Gaspar Melchor de Jovellanos. Colección hecha e ilustrada por D. Cándido Nocedal. Madrid, Rivadeneyra, 1859, vol. II.

${ }_{20}$ Publicadas por vez primera en la Colección de varias obras en prosa y verso... Ob. cit., vol. V. Con notas de Cañedo, 1830-2. 
estilos y construidos mayormente durante el reinado de Jaime II (12761311), le hicieron (como antes a los cronistas locales) reivindicar esta etapa como la de mayor esplendor económico, político y cultural de la historia de Mallorca, idea que desarrollaron desde 1840 Pablo Piferrer (1818-48), Antonio Furió (1798-1853), Joaquín M. ${ }^{a}$ Bover (1810-65) o José M. ${ }^{a}$ Quadrado (1819-96).

Sobre la Catedral de Palma ${ }^{21}$, cuyo exterior había descrito Jovellanos en su Descripción panorámica desde el Castillo de Bellver, se ocupó en su Descripción de la Catedral de Palma (1807-8) ${ }^{22}$. En esta carta narró la historia de la construcción de la Catedral con gran erudición. Utilizó como fuentes los libros de fábrica de la iglesia y archivos del Cabildo, junto a las crónicas de Dameto y Mut y criticó las aportaciones de otros historiadores locales como Alemany, Tarrasa, Cayetano de Mallorca y Serra. Agradeció al canónigo mallorquín José Barberí las ayudas prestadas como proveedor de fondos documentales catedralicios ${ }^{23}$.

Esta carta, que iba acompañada de dibujos de la Catedral para proporcionar a Ceán Bermúdez una idea más exacta sobre ella ${ }^{24}$, incluía también comentarios artísticos sobre el templo. En su Disertación sobre el traslado del coro de la Catedral de Palma (Barcelona, S.A.) ${ }^{25}$, breve obra escrita con posterioridad a su estancia en Mallorca, Jovellanos contradijo sus anteriores críticas a la situación central del coro, y se mostró conforme con su emplazamiento.

21 El erudito mallorquín Antonio Furió publicó, adicionada y rectificada con notas suyas, una supuesta carta de Jovellanos sobre la Catedral; ver Jovellanos, G.M. de. Carta históricoartística sobre el edificio de la iglesia Catedral de Palma en Mallorca. Palma, Imp. de Felipe Guasp, 1832. Se tuvo por obra de Jovellanos, y así fue considerado por los autores del período romántico, hasta que Julio Somoza la comparó con su Descripción de la Catedral de Palma (1807-8), manuscrito del Archivo Fuertes Acevedo que publicó en su libro Escritos inéditos de Jovellanos. Barcelona, Tip. Artes y Letras, 1891.

Somoza comprobó la existencia entre ambas obras de diferencias de criterios, estilo, notas, encabezamiento y final del manuscrito, y atribuyó la primera al canónigo y erudito mallorquín José Barberí; ver SOMOzA DE MONTSORIU, Julio, Inventario de un jovellanista. Madrid, Suc. de Rivadeneyra, 1901, pág. 39. Esta tesis fue compartida por FERnÁndez y González, A.R., Jovellanos y Mallorca. Ob. cit., págs. 201-2.

22 Publicada por vez primera en Somoza de Montsoríu, Julio, Escritos inéditos de Jovellanos. Ob. cit. Es el vol. IV de las Obras escogidas de... Ob. cit. Hay que destacar que dado lo tardío de su publicación (1891) los eruditos de la etapa romántica lo desconocieron.

23 Ver GUASP I VICENS, F., "Jovellanos I Barberi", Ob. cit.

${ }^{24}$ Barón Thaidigsmann apunta que Jovellanos mandó hacer dibujos de la planta, sección y detalles de la Catedral, igual que del Castillo de Bellver. Los dibujos serían realizados por Barberí, Francisco Tomás y Martínez Marina. Ver BArón Thaidigsmann, Javier, Ideas de Jovellanos sobre arquitectura... Ob. cit., pág. 42.

25 Publicado por vez primera en Fernandez y González, A.R., Jovellanos y Mallorca. Ob. cit., págs. 63-81. Iba dirigida a José Barberi, al parecer para oponerse al traslado del coro a la parte trasera del altar Mayor, que pensaban hacer los canónigos de la Catedral. 
Los últimos escritos sobre arquitectura mallorquina del polígrafo gijonés están en su Diario decimotercero $(1808)^{26}$. Tras su liberación, visitó en Palma los edificios que sólo conocía por referencias o vistos desde el Castillo y emprendió un viaje por la isla, visitando algunas poblaciones, antes de embarcar para Barcelona el 19 de mayo. En este diario hizo breves descripciones sobre edificios como Sto. Domingo, S. Francisco, Sta. Eulalia, Montesión, Sta. Magdalena y también de la iglesia y convento de Capuchinos, de la iglesia del Carmen y de la de Capuchinas. También hizo breves referencias de las iglesias de Sóller, Binisalem, Ntra. Sra. de Randa, Alcudia, Algaida, Sineu, parroquial de Pollensa, etc. dedicando elogios a la colección de esculturas y antigüedades reunida por el cardenal Despuig en Raxa y visitando las murallas y el teatro romano de Alcudia.

Las cartas bellverianas sobre la arquitectura gótica palmesana y los escritos sobre la arquitectura inglesa y la gótica, significaron una evolución en la obra de Jovellanos que estuvo marcada por el tránsito de una ideología ilustrada y racionalista a otra prerromántica, influenciada por autores como Rousseau, Burke y Shaftesbury.

Esta evolución en su obra, cuyas raices están en la vena subjetiva, sentimental, medievalista surgida del propio seno de la llustración, se hizo patente en un Jovellanos que quema los últimos años de su vida, encerrado por razones políticas y pesimista respecto a la marcha de los tiempos. Su contacto con una Mallorca marcada por el esplendor medieval y concretado en sus principales edificios góticos, y la necesidad de evadirse de su triste situación, le llevaron a cuestionar los principios ideológicos que habían regido su etapa anterior y a valorar aspectos artísticos ${ }^{27}$ ya apuntados pero no suficientemente desarrollados anteriormente.

26 Publicados por vez primera en SOMOZA DE MONTSORíu, J., Escritos inéditos de Jovellanos. Ob. cit. Es el vol. IV de las Obras escogidas de... Ob. cit. Escrito entre Mallorca y Guadalajara tras su liberación, y fechados entre el 5 de abril y el 23 de junio de 1808.

${ }^{27}$ "Jovellanos fue un prerrománico calificado. No sólo en la segunda etapa de su vida (desde la prisión en el castillo de Bellver), sino en la primera también -exaltación del arte gótico, y en general, del medieval español-, muestra matices románticos acusados, que luchan voraces contra el neoclasicismo imperante, al que rinde tributo. Pero por encima de esto, se anticipó al vizconde de Chateubriand (Genio del cristianismo, 1802) en la exaltación del arte cristiano de la Edad Media; y el romanticismo de la novela histórica de Walter Scott lo advirtió con júbilo Jovellanos el primero en España". ARCO, Ricardo del, "Jovellanos y las Bellas Artes", Revista de Ideas Estéticas, n. ${ }^{\circ}$ XIII. Madrid 1946, pág. 32. Señala el autor cómo su destierro en Mallorca "avivó en él - tan clasicista-su devoción a la Edad Media", pág. 58.

Sureda Blanes también insiste en los cambios ideológicos en materia artística que sufre Jovellanos: «En este profundo silencio van a despertarse las verdades adormecidas y a desvanecerse todos los restos que en el preso quedaban de la ideología del siglo XVill'. SUREDA Blanes, José, Jovellanos en Bellver. Ob. cit., pág. 11. 
Dentro de la historia local Jovellanos tendió a resaltar lo positivo, y los episodios de mayor gloria y grandeza que, en el caso de Mallorca, se enmarcaban entre los siglos XIII y XIV con la monarquía privativa y el auge comercial logrado en el Mediterráneo. De esta época son las pricipales construcciones góticas que Jovellanos trató en sus cartas.

En los edificios góticos mallorquines vio plasmada Jovellanos la época dorada de la isla y la identidad religiosa y cultural de sus pobladores, y en el gótico su estilo nacional. Este entusiasmo por el gótico no significó que sus gustos clasicistas pasasen a un segundo plano, pero abrió la puerta al fin del exclusivismo clasicista y al eclecticismo decimonónico, caracterizado por la recuperación de los estilos medievales.

Los grandes edificios góticos de Palma no sólo fueron juzgados por Jovellanos en función de su mayor o menor seguimiento de las normas clasicistas, sino en función de otros criterios de base emocional y religiosa ${ }^{28}$. Si racionalmente prefería las obras clásicas, las góticas provocaban en sus sentidos un entusiasmo más vivo. Construcciones grandiosas, majestuosas, misteriosas, capaces de emocionar y conmover el espíritu y llenas de originalidad e idealismo, por ser reflejo de una sociedad cristiana donde el arte tendió a plasmar la expresión de lo divino, trascendiendo sobre los aspectos formales.

Jovellanos se anticipó también a los autores romáticos al denunciar el abandono en que se hallaban edificios como el Castillo de Bellver, el antiguo puerto de Porto-Pi o la misma Catedral, que presentaba grietas en sus muros y bóvedas de los pies. $Y$ es que ese patrimonio monumental en vías de extinción ante el descuido gubernamental, era el más vivo reflejo del esplendor nacional de antaño. Autores como Furió, Bover, Piferrer o Quadrado se hicieron eco de esta preocupación, instando a la administración a la conservación del patrimonio y sensibilizando a la opinión pública con su pluma.

${ }^{28}$ «El gótico dejó de ser la manera bárbara de que había hablado en su Elogio de las Bellas Artes, y pudo ver cuán falsas eran las afirmaciones que había sentado en dicho escrito... que recalca aún más en su Elogio de $d$. Ventura fodriguez, siempre que su idea fija del sistema de proporciones... A esta concepción fría y razonadora, oponían las grandes construcciones mallorquinas de la gran época de Jaime II, su espiritualidad, su tendencia a la elevación y al misterio, su inspiración, sin dejar por ello de tener una sólida base razonadora, no vislumbrada por Jovellanos. En los viejos picapedreros medievales... habia, además de la técnica, un robusto creador que los lanzaba a las mayores audacias. Contra lo que había pensado Jovellanos, supieron encontrar la belleza en su idea que, esencialmente, consistía en dar supremacía a las razones de orden religioso y estético sobre cualquier otra especie de razones". SUREDA BLANES, José, Jovellanos en Bellver. Ob. cit., págs. 19-20. 
Recursos característicos del romanticismo como el amor al paisaje, el subjetivismo descriptivo, la fantasía y la evocación poética, la nostalgia o el sentimentalismo en el discurso racionalista, son patentes en su Descripción histórico-artística del Castillo de Bellver, su obra más prerromántica ${ }^{29}$, y es toda una muestra de la afirmación del individualismo burgués tan característico del movimiento romántico.

Junto a estos elementos prerrománticos, en los escritos de Jovellanos están presentes otros de marcada raíz ilustrada y neoclásica, lo que hace que, como crítico e historiador del arte, lo tengamos por una figura de transición entre el neoclasicismo dieciochesco y el eclecticismo decimonónico.

Sus críticas del arte barroco recargado (churrigueresco) desarrollado en España por Churriguera, Tomé o Ribera ${ }^{30}$ fueron tan crueles como las de Ponz. En esto no variaron sus primeros escritos de arte Elogio de las Bellas Artes o el Elogio de d. Ventura Rodríguez de las cartas de arquitectura mallorquina. Fue otro aspecto del neoclasicismo que también heredaron los autores románticos. Como clasicista, racionalmente nunca dejó de considerar dicho arte como el más meritorio, y las normas clasicistas normas universales. Esto se manifiesta claramente en las obras anteriores a su estancia en Mallorca, pero también en las escritas en Bellver.

Respecto a su admiración por la arquitectura gótica, ésta ya existió en críticos ilustrados como Ponz o Capmany ${ }^{31}$, y los edificios mallorquines eran bien vistos por Serra o Vargas Ponce, y en general por todos los viajeros de la época. Juzgada con criterios de valor clasicistas, supo cap-

29 "El fenómeno prerromántico, sobre todo, responde a simples reacciones individuales, a una determinada manera de sensibilidad ...y una anticipación de aspectos que el romanticismo elaborará después". ARCE FERNÁNDEZ, Joaquín, “Jovellanos y la sensibilidad prerromántica», Boletín de la Biblioteca Menéndez y Pelayo, t. XXXVI. Santander 1960, pág. 141.

30 «Edad de corrupción, abandonados otra vez los principios del arte de edificar, volvió a adoptar el capricho de los arquitectos todas las extravagancias que había inventado el de los escultores y pintores. Aquellos convertidos en tallistas, para servir en los templos a una superstición tan vana y tan ignorante como ellos, alteraron todos los módulos, trastocaron todos los miembros, desfiguraron todos los tipos del ornato arquitectónico una, muchedumbre de nuevas formas, si muy distantes de la sencillez y majestad de las antiguas, mucho más todavía de la decencia y el buen gusto... todo se cubrió de torpes garambainas y groseros follajes; monumentos ridículos que testifican todavía la barbarie de quien los hacía y el mal gusto de quien los pagaba», Jovellanos, G.M. de, Elogio de d. Ventura Rodriguez. Ob. cit., págs. 30-2.

${ }_{31}$ Ponz, Antonio, Viage de España. Madrid, Ibarra, 1776-94, XVIli vols. (facs., Madrid, Atlas, 1972); Capmany y MontPalau, Antonio de, Memorias históricas sobre la marina, comercio y artes de la antigua ciudad de Barcelona. Madrid, 1779-92, IV vols.; ver AzCÁRATE, José M. " de, "Valoración del gótico en la estética del siglo xvIII”. Simposio El P. Feijoo y su siglo, Cuadernos de la cátedra Feijoo, vol. III, n. ${ }^{\circ} 18$. Universidad de Oviedo, 1966, págs. 525-49. 
tar Jovellanos en la arquitetura gótica palmesana, el contenido espiritual que animaba y dislocaba sus formas, y la lógica e interrelaciones de sus distintos elementos constructivos y decorativos. Ello abrió camino a la recuperación nacionalista del arte medieval y especialmente del gótico, de la mano de los críticos románticos que, como Piferrer o Quadrado, fueron devotos del mismo. Esta ruptura del monopolio del gusto clasicista y la reivindicación del estilo gótico, a través de los edificios palmesanos, fue obra, sobre todo, de Jovellanos, y a lo largo del siglo XIX derivó en la recuperación de los estilos medievales.

\section{VISIÓN DE LA ARQUITECTURA GÓTICA DE PALMA}

El interés de Jovellanos se centró en las tres obras más significativas de la arquitectura gótica palmesana: la Catedral, la Lonja y el Castillo de Bellver. En segundo lugar en cuanto a preferencias, situó Jovellanos los conventos también góticos de Sto. Domingo y S. Francisco. De otras obras hay breves referencias a las murallas de Palma, el conjunto de Porto-Pi, y algunas iglesias como Sta. Eulalia, Montesión, etc.

1. La Catedral. Jovellanos hizo una detallada narración de la edificación del templo, y su ubicación en el lugar donde estuvo la mezquita principal. Atribuyó las trazas al maestro Nicolás, y su inicio hacia $1230^{32}$, en que se emprendería la construcción de la capilla Real, su parte más antigua. De entre los maestros que intervinieron en su construcción destacó a Pedro Morey, autor de la portada del Mirador. Entre las partes de la Catedral preferidas por Jovellanos estaban su propio exterior gótico y la portada del Mirador (sur), del mismo estilo. Junto a ellas, Jovellanos resaltó también las partes del siglo XVI (la portada Principal, el coro y los púlpitos).

De su exterior, descrito por Jovellanos en su Descripción Panorámica desde el Castillo de Bellver, dijo que:

«Sobre todos descuella majestuosamente la iglesia Catedral, que colocada en eminente situación... y levantándose con sus torres a muy grande altura, aparece entre los demás edificios como una grande almiranta en medio de pequeñas corbetas y faluchos" ${ }^{33}$.

32 Las obras no se iniciaron hasta principios del siglo xIV, siendo desconocido el autor de su pian. Ya desde las crónicas de Binimelis, Dameto y Mut se creía que fue iniciada con Jaime I. Jaime Villanueva negó esta fecha, asegurando que no se inició hasta el reinado de Jaime II. Ver VIlLANUEVA, Jaime, Viaje literario a las iglesias de España. Madrid, Imp. de la Real Academia de Historia, 1851-2, vol. XXI, págs. 101-3.

33 Jovellanos, G.M. de, Obras publicadas e inéditas de... Ob. cit., vol. LXXXVII, pág. 360. 
De la fachada principal señaló que era muy sencilla, con dos hermosas torres octogonales en sus ángulos, dos altos y estrechísimos pilastrones que la dividian perpendicularmente en tres partes, dos ventanas circulares en las naves laterales, y en la del medio un enorme rosetón y una magnífica portada al pie. "Falta empero, a este ornato su gracia principal: esto es la balaustrada,... Con todo, en medio de tanta sencillez, brilla el más puro gusto de la arquitectura ultramarina del primer tiempo" ${ }^{34}$.

Del flanco sur que mira al mar, destacó su robustez y prominentes estribos, "pues que tiene el aire de un vasto edificio escondido todavía tras de su enorme andamiada, y recuerda a la idea de aquellos grandes castillos de madera que se construían en la guerra de ultramar" ${ }^{35}$. También se fijó el autor en la falta de ventanas y el cegamiento de buena parte de las existentes, lo que imaginó para «disminuir la luz en favor de la devoción» ${ }^{36}$.

Pese a no ajustarse a las normas clasicistas, no pudo ocultar Jovellanos su entusiasmo ante tal obra gótica:

"Más, a pesar de que estas faltas de euritmia y de una forma tan extraña prometen poco favorable efecto, el que produce el todo de esta obra, sin ser bello ni elegante, tiene un no sé qué de grande y majestuoso que sorprende y agrada notablemente a la vista ${ }^{37}$.

Sus portadas y el interior de la iglesia están descritas en su Descripción de la Catedral de Palma. La pieza gótica que más admiración le causó fue la portada del Mirador (sur), que atribuyó al mallorquín Pedro Morey (siglo xIV) y que quedó inacabada. Si de la portada de la Almoina (norte), también gótica de finales de siglo $x \mathrm{~V}$, decía que «es admirable por su noble sencillez", prefirió la del Mirador: "por la delicada y riquísima es-

${ }^{34}$ Jovellanos, G.M. de, Ibidem. Se refiere a la fachada anterior a la neogótica actual, obra de Peyronnet, sustituida tras la ruina provocada por el terremoto de 1851.

35 Jovellanos, G.M. de, Ibidem. Para Jovellanos, que no tuvo en cuenta las aportaciones románicas y cistercienses en el origen del gótico, esta arquitectura tenía un origen ultramarino (oriental) y fue traida a Europa por los cruzados

${ }^{36}$ JovelLanos, G.M. de, Obras publicadas e inéditas de... Ob. cit., vol. LXXXVII, pág 361. Parte de las ventanas y vidrieras estaban cerradas para dar mayor consistencia a los débiles muros del edificio y para evitar que el fuerte viento las rompiese. La gran altura de la bóveda central y la falta de apoyos adecuados hizo que poco después de terminarse, empezasen a surgir grietas que pusieron en peligro la obra. Buena parte del frontispicio se vino abajo tras el terremoto de 1851.

${ }^{37}$ Jovellanos, G.M. de, Ibidem. 
cultura en que resplandecen, así el espíritu del Cabildo, como el talento de su autorm ${ }^{38}$.

Consideró que las partes del siglo XVI eran las que más contribuían a la magnificencia del templo. De la portada principal escribió que era:

«la última y más preciosa obra del templo... por su grandeza y por la riqueza de su escultura y arquitectura, es digna de la majestad de tan insigne edificio" ${ }^{39}$

Fue costeada por el obispo Vich y Manrique a finales del siglo xVI. De estilo manierista, compuesta por dos cuerpos con columnas, estatuas y elementos decorativos platerescos y rematada por un arco de medio punto encasetonado, destaca en el tímpano sobre el parteluz la imagen de la Inmaculada, a quién se dedicó el templo, rodeada de los símbolos del misterio. Decía que la escultura era del más puro gusto de aquella época y que la arquitectura de la portada "pertenece a la época que sucedió al gusto ultramarino, en cuyo género iguala a las más bellas» ${ }^{40}$; indicó que estaba realizada con piedra de Santanyí y que era obra de Antonio Fornari ${ }^{41}$.

Alababa la portada del coro y los adornos de su espalda:

"Es un gracioso cuerpo de arquitectura adornado con dos columnas sobre las que corre un bello cornisamento en que descansan dos estatuas a uno y otro lado del ático que en medio se levanta. Tiene esa fachada dos frentes, pero así la interior como la exterior del trascoro están enriquecidas con hermosos medallones y entalladuras del mejor gusto y de la más diligente ejecución, según la manera italiana» ${ }^{42}$.

Fechó esta obra hacia 1525-30, atribuyéndola al aragonés Juan de Salas, introductor en Mallorca del estilo plateresco y anotando erróneamente la colaboración de un tal Magimari o Máximo Martín ${ }^{43}$. Señaló Jovellanos que del mismo autor eran los púlpitos, "sobremanera y no sin justicia ponderados, por la delicadeza y gusto de su escultura» ${ }^{44}$. De la

38 Jovellanos, G.M. de, Obras publicadas e inéditas de... Ob. cit., vol. LXXXVII, pág. 394.

39 Jovellanos, G.M. de, Obras publicadas e inéditas de... Ob. cit., vol. LXXXVI, pág. 401.

40 Jovellanos, G.M. de, Ibidem.

41 Es obra del arquitecto manierista Miguel Verger, en las esculturas participó Jaime Blanquer.

42 Jovellanos, G.M. de, Obras publicadas e inéditas de... Ob. cit, vol. LXXXVII, pág. 398.

43 Piferrer descubrió el error de Jovellanos al leer el documento, confundiendo Magin Mari - Magimari por "ymagynaire" o imaginero. PIferren, Pablo, Recuerdos y bellezas de España. Mallorca. Barcelona, J. Verdaguer, 1842, págs. 187-8.

44 Jovellanos, G.M. de, Ibidem. 


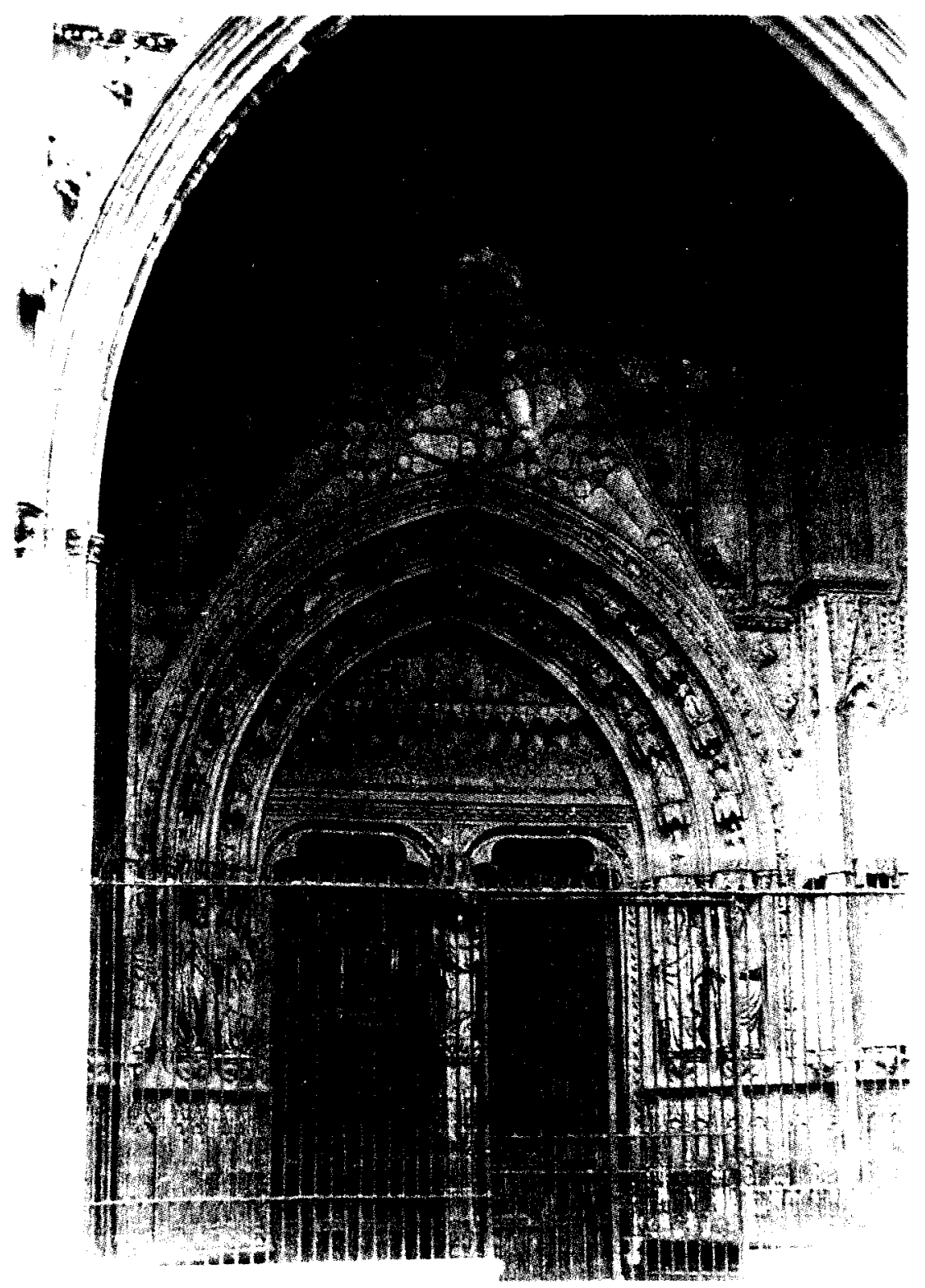

Fig. 1. Puerta del Mirador de la Catedral de Palma. 


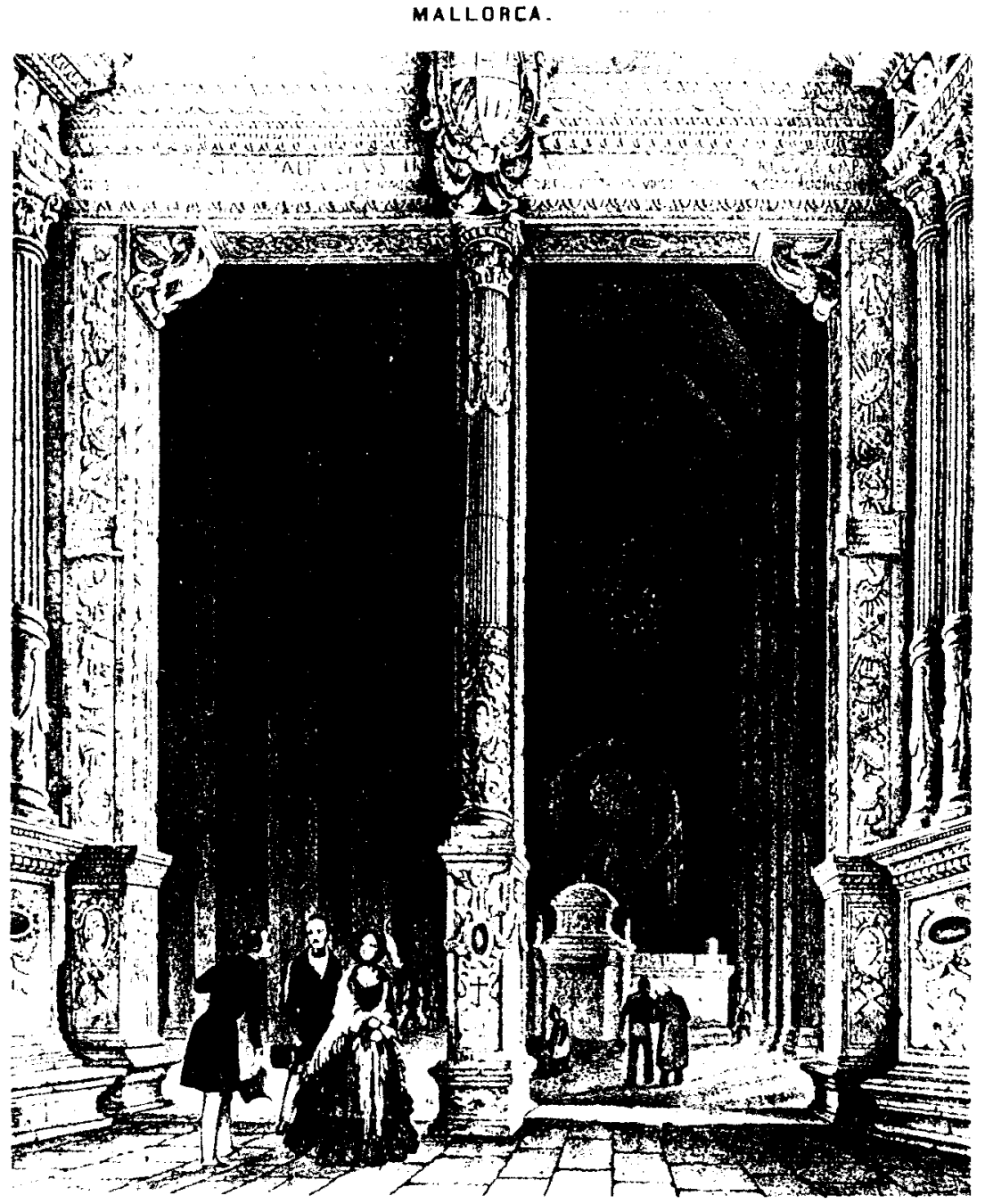

Fig. 2. Interior de la Catedral de Palma desde el Portal Mayor. Dibujo y litografía de F. J. Parcerisa. En Piferrer, Pablo, Recuerdos y bellezas de España. Mallorca. Barcelona 1842. 
sillería del coro, gótica, apuntaba que fue traída de Génova, siendo una hermosa obra de gran primor y excelencia.

El aspecto más negativo de la Catedral era para Jovellanos la situación central del coro que rompía la perspectiva interior, algo compartido por todos los críticos neoclásicos y lamentado en las catedrales españolas; sin embargo, en su Disertación sobre el traslado del coro de la Catedral de Palma, se mostró contrario a colocarlo tras el altar Mayor, por ser su situación común a las catedrales españolas, permitir la distribución de los cánticos desde el centro y paliar la sensación de extrema desnudez del interior del templo ${ }^{45}$.

También habló del inacabado campanario gótico (Torre del Clocher), sito en el costado norte. Su orientación no coincidente con el muro norte catedralicio le indujo a error, al considerarlo anterior a la traza de la Catedral, creyendo fuese el alminar de la antigua mezquita musulmana" ${ }^{46}$.

2. La Lonja. Jovellanos trazó la historia de su construcción en su Descripción histórico-artística de la Lonja de Palma. Ésta no se llevó a cabo hasta el siglo xv, entre 1426-49, siendo obra del mallorquín Guillermo Sagrera. También citó Jovellanos los nombres de los artistas que trabajaron en las últimas esculturas y obras exteriores hacia 1451, Guillermo Villasolar y Miguel Sagrera. En su Descripción Panorámica desde el Castillo de Bellver, describió su exterior e interior. Jovellanos se guió por su formación neoclásica, resaltando la sobriedad y armónica distribución de la decoración y las proporciones regulares del edificio, no lejanas de las clasicistas, y por su admiración ante las portadas, el cornisamiento o las columnas helicoidales de factura gótica. Esta mezcla de regularidad clasicista con la gracia y finura de elementos y ornamentación góticos, fue 10 más apreciado por Jovellanos y otros autores ilustrados.

Jovellanos definía la Lonja como un edificio cuadrilongo y aislado, haciendo hincapié en su sobriedad:

"y es tan recomendable por su noble sencillez como por la sabia distribución de su ornato" ${ }^{47}$.

\footnotetext{
45 "No puede negarse que quitando el coro de enmedio de la Catedral de Mallorca, aquel vasto edificio representaría un golpe de vista muy espacioso. Pero cuanto más espacioso, más pobre... el edificio es magnífico por su tamaño y delicadeza de sus pilares o columnas; pero está enteramente desnudo de aquellas bellezas y primores del arte que suelen ennoblecer a semejantes edificios mosaicos", en FernÁNDEZ y GonzALEZ, A.R., Jovellanos y Mallorca. Ob. cit., pág. 70. Esta sensación de excesiva desnudez interna será también resaltada por los viajeros e historiadores del romanticismo.

${ }_{46}$ JoVellanos, G.M. de, Obras publicadas e inéditas de... Ob. cit., vol. LXXXVII, pág. 391.

7 Jovellanos, G.M. de, Obras publicadas e inéditas de... Ob. cit, vol. LXXXVII, pág. 362
} 
La describió exteriormente diciendo que sus muros estaban cortados perpendicularmente por pilastrones octógonos, y divididos horizontalmente en dos partes iguales por una cornisa o imposta de escaso resalte, estando sus ángulos flanqueados por cuatro torres octogonales de un solo cuerpo muy esbelto. Pero lo que más llamó la atención de Jovellanos fue su "grandiosa y bella balaustrada o cornisamento" ${ }^{48}$ de grandes recuadros perforados, coronada como las torres y pilastrones de almenitas y merlones triangulares, que:

"por sus proporciones como por su nueva, extraña y caprichosa forma, es del más precioso efecto y ennoblece considerablemente el edificio... así como para que no chocase al exterior la grande altura del edificio lo dividió en dos cuerpos, cuando en realidad sólo tiene uno, también para suplir la falta aparente de luces, ..., dio a su cornisamento aquella hermosa pero extraña forma de ventanaje, que disipa esta idea, sin que por ello deje de concurrir a la belleza de la obras ${ }^{49}$

De su ornamentación escultórica destacó la de las criquísimas portadas", utilizadas seis como ventanas y cuatro como entradas. "Grandes todas, elevadas hasta tocar la imposta con la cresta de sus cabeceras rellenas; pero perforada la luz alta de sus arcos punteados con graciosos arabescos, y enriquecidas, además, con todo el lujo y delicadeza de la antigua crestería, parecen inventadas... para ...ostentar la opulencia de la profesión a que se destinaba este edificion ${ }^{50}$. Por todo ello:

"no extrañará que yo cuente a la Lonja de Mallorca entre los mejores edificios civiles que conserva España del gusto ultramarin»" ${ }^{51}$.

De su interior señalaba que no era menos magnífico. Una sala rectangular dividida en tres naves por seis altas y hermosas columnas estriadas desde el suelo en espiral, sin capiteles ni impostas, que se corresponden con los pilastrones exteriores. De los nervios de las bóvedas de crucería del edificio apuntaba que:

"Todos ellos nacen y arrancan del tronco de las columnas como del de una erguida palma las magníficas ramas de pluma que se encorvan en torno a él y la coronan, y para que todo sea singular en estas colum-

48 Jovellanos, G.M. de, Ibidem.

49 Jovellanos, G.M. de, Obras publicadas e inéditas de... Ob. cit., vol. LXXXVII, pág. 363.

so Jovellanos, G.M. de, Ibidem.

51 Jovellanos, G.M. de, Ibidem. 


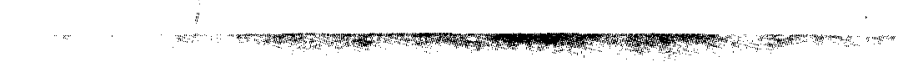

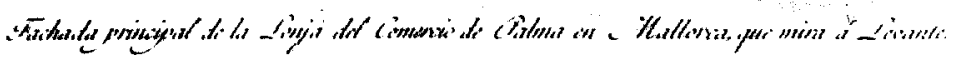

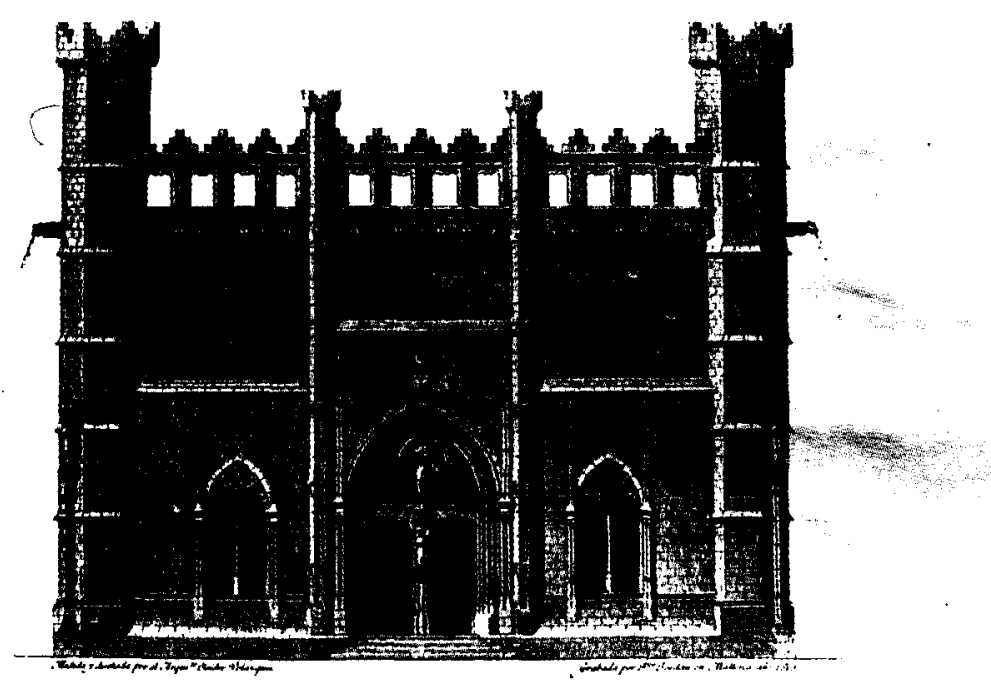

Fig. 3. Fachada principal de la Lonja del Comercio de Palma en Mallorca, que mira a Levante. Dibujo de Isidro Velázquez, calcografía de Francisco Jordán. Mallorca 1813.

nas, sus bases sólo se distinguen del fuste en su mayor diámetro... cuán grande y extraña será la hermosura del interior de esta obra» ${ }^{52}$.

3. El Castillo de Bellver. Sus datos históricos los incluyó Jovellanos en sus Memorias del Castillo de Bellver. Apéndice primero. Obra comenzada a principios del siglo xiv y edificada con piedra del propio cerro de Bellver, de Portals y de Santanyí, atribuyó su autoría al mallorquín Pedro Salvá y la consideró terminada hacia $1309^{53}$. Señaló Jovellanos que fue

52 Jovellanos, G.M. de, Ibidem.

55 Los libros de fábrica anteriores a 1309 se perdieron, siendo desconocido el autor de su traza. En 1309 figuraba Pedro Salvá al frente de las obras. 


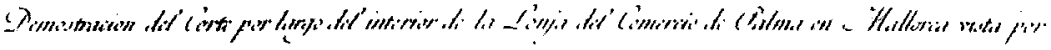

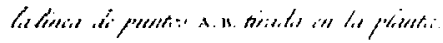

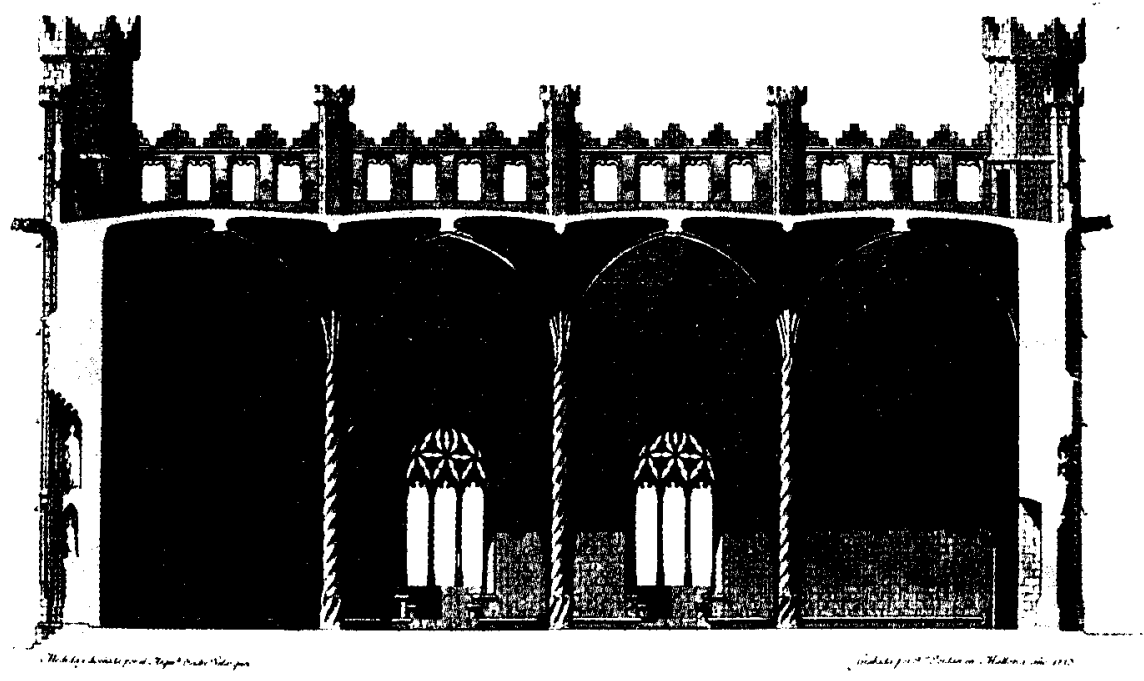

Fig. 4. Demostración del Corte por largo del interior de la Lonja del Comercio de Palma en Mallorca. Dibujo de Isidro Velázquez, calcografía de Francisco Jordán. Mallorca 1813.

mandado construir por Jaime II para residencia de descanso y recreo, diciendo que era «la primera de las obras militares que existen de aquella edad" ${ }^{54}$.

La descripción formal y artística del Castillo es exhaustiva en su Descripción histórico-artística del mismo. Como clasicista apreció su disposición centralizada y geométrica, simetría y sobriedad decorativa. Como amante del gótico, alabó la gracia y ligereza de sus arcos apuntados y bóvedas de crucería. Los aspectos más resaltados fueron sin duda sus arcos y bóvedas góticos y la galería circular del primer piso; tampoco olvidó señalar el efecto impresionante de su torre del Homenaje.

54 Jovellanos, G.M. de, Memorias históricas sobre el Castillo de Bellver... Ob. cit., pág. 20. 
Describió el Castillo como recinto de forma circular, con su muro exterior interrumpido por tres torreones redondos y mochos; entre ellos cuatro garitones también circulares y en su altura otro cubierto y elevado sobre ella. De estos garitones indicó que se apoyaban sobre cuatro colosales columnas resaltadas del muro, cuya parte inferior estaba rodeada por un foso. Separada por el foso y en el lado libre de torreones estaba la torre del Homenaje, de más de cuarenta y cinco pies de alto, comunicada por un puente con la plataforma ${ }^{55}$.

Del interior decia que estaba compuesto por un patio circular y dos galerías superpuestas que daban acceso a las habitaciones, señalando que "la belleza del todo es grande y digna de ser más conocida» ${ }^{56}$. De las bóvedas de crucería decía que:

"Lo primero que admira en su interior es la osadía de las bóvedas que cubren las habitaciones. Volteadas en torno entre muros circulares y concéntricos, y sostenidas en grandes, pero estrechas y muy resaltadas fajas octágonas, que representan arcos encontrados y cruzados en lo alto, es visto de cuán gracioso y extraño efecto serán" "57.

Para el autor, lo más notable de ellas era su apariencia grácil que escondía su verdader solidez, al aparecer estas bóvedas apoyadas en débiles fajas, y sin más apoyo que el de unas pequeñas impostas en forma de repisas, voladas al aire de trecho en trecho como a un tercio de altura de la pared interior. Estas repisas eran el punto de arranque de los numerosos arcos, agrupados de tres en tres, que cruzaban la bóveda de un lado al otro para volver a caer en las repisas fronteras. Por ello:

«es fácil concebir cuán extraña y graciosa será su apariencia, y cuánto gusto y pericia supone la simétrica degradación de estos arcos, que enlazándose por todas partes y en todos sentidos entre tan desiguales muros, producen la más elegante y caprichosa forma» ${ }^{58}$.

Los mismos elogios dedicó a las bóvedas de la galería alta, que siguen la misma degradación en proporciones más reducidas, péndulas sobre pequeñas impostas. Elogió la belleza de esta galería alta, compuesta por veintiún arcos apuntados apoyados sobre columnas octogonales iguales entre sí, pese a ligeras diferencias entre sus módulos, plintos, etc. Destacó

55 Jovellanos, G.M. de, Obras publicadas e inéditas de... Ob. cit., vol. XLVI, pág. 393.

Jovellanos, G.M. de, Ibidem.

JovelLanos, G.M. de, Ibidem.

58 Jovellanos, G.M. de. Obras publicadas e inéditas de... Ob. cit., vol. XLVI, pág. 394 


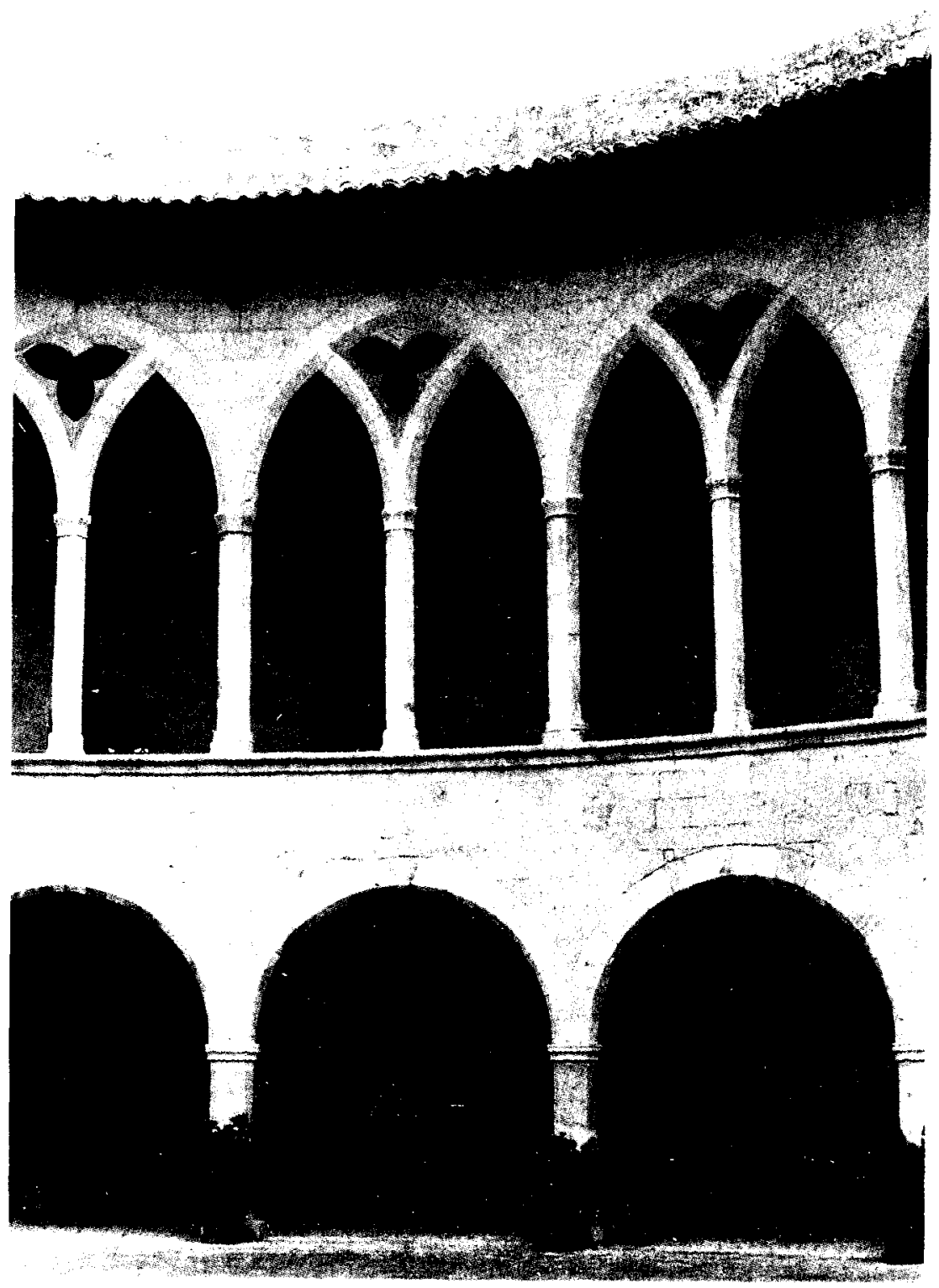

Fig. 5. Patio del Castillo de Bellver. 


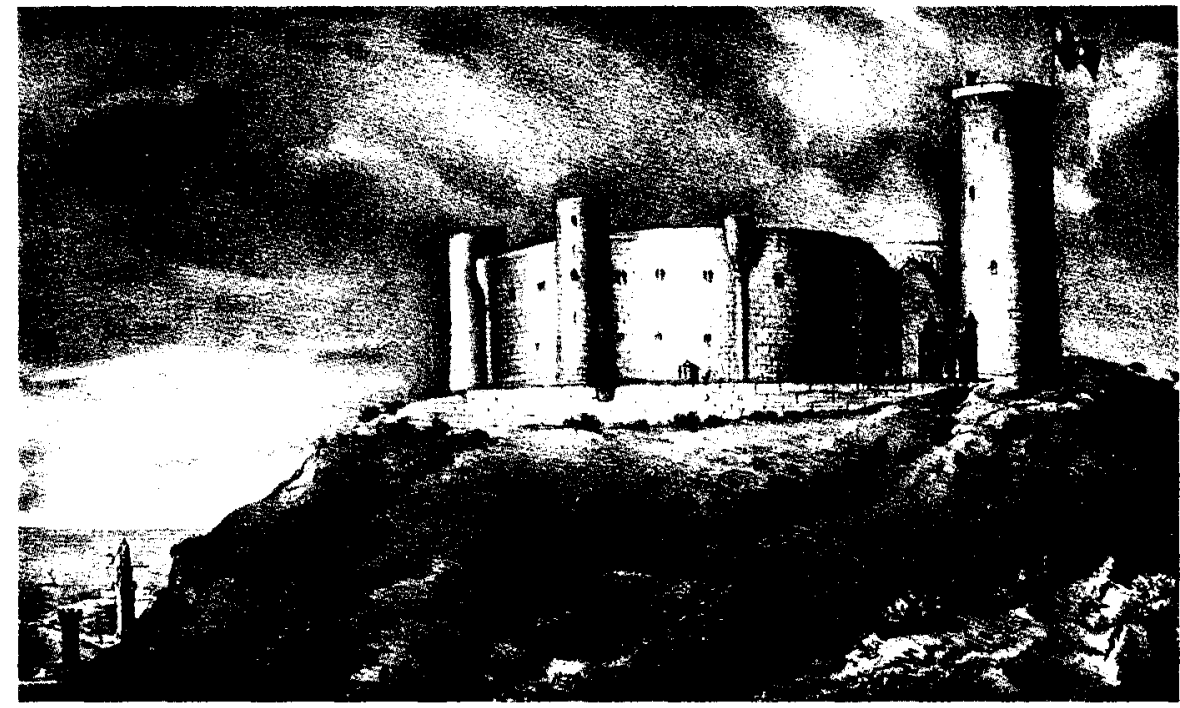

Fig. 6. Bellver. Litografía sin firma En Socías, Cayetano, Reyes de Mallorca. Palma 1852.

que cada tres columnas sostenían un arco doble, estando colocadas a iguales distancias, con gran sentido de la simetría. De los arcos de esta galería terminaba diciendo:

"Y como todos se vayan enlazando entre si y las enjutas de los arcos pequeños están perforadas con sencillo y gracioso dibujo arabesco, ...visto es cuán magnifica y armoniosa será esta galería” ${ }^{59}$.

Sobre la galería inferior, recordó que sus arcos eran de medio punto, y se correspondian con la de los de la galería superior, estando apoyados sobre fuertes pilares de ángulos achaflanados.

4. Sto. Domingo. De los conventos de Sto. Domingo (demolido en 1837) y S. Francisco escribió Jovellanos con amplitud en su Memoria sobre las fábricas de los conventos de Sto. Domingo y S. Francisco de Palma, haciendo breves alusiones a ellos en su Descripción Panorámica desde el Castillo de Bellver y en su Diario decimotercero.

59 Jovellanos, G.M. de, Ibidem. 
Los aspectos más destacados por Jovellanos fueron la alta bóveda de crucería de su iglesia y la caprichosa antecámara o antecapítulo que precede al claustro grande, también gótica. Criticó asimismo los aditamentos churriguerescos de la iglesia siguiendo las Varias noticias relativas a MaIlorca... (Mss.) ${ }^{60}$ de Buenaventura Serra.

Lo consideraba como uno de los primeros conventos levantados tras la conquista, y construido entre 1296 y 1359. Entre sus arquitectos, estaria el mallorquín Jaime Fabra, que trabajó en la Catedral de Barcelona desde 1317. Según la crónica manuscrita del convento, éste sería su único artífice.

Describió la iglesia como de una nave, con una elevada y bella bóveda de crucería apoyada sobre altas y delgadas columnas, capillas laterales con grandes arcos de entrada y presbiterio semicircular. Destacó ente sus capillas la de Ntra. Sra. del Rosario (1480-1517), remodelada a principios del siglo XVIII por fray Alberto Burguny, según el gusto churrigueresco. Esta pieza, muy criticada por Serra y cuyas críticas transcribió literalmente Jovellanos, le sirvió igualmente al gijonés para descargar sus iras contra el barroco, lamentando la desaparición de los antiguos cuadros:

«Hízolos desaparecer el mal gusto en una remodernación que a la entrada del último siglo hizo en esta capilla Fr. Alberto Burguni, religioso de la misma casa, el cual a las bellas pinturas que allí habia sustituyó los feos retablos que se ven hoy, llenos de garambainas y relumbrones, según la moda de aquel tiempo» ${ }^{61}$.

Del claustro más pequeño dijo que tenía algo de caprichoso en su apariencia, pues las columnas aisladas que sujetaban sus arcos apuntados eran elíptico-octágonas, señalando que Fabra les dio esta forma para aumentar la luz de los arcos, dejando entre ellos el diámetro menor de la elipse, y dando al tiempo mayor esbeltez a las columnas. Del claustro grande señaló que era muy sencillo, con arcos también apuntados que apoyaban sobre estribos lisos.

Del capítulo señaló que era pieza grande y hermosa, y se detuvo ante su antecámara o antecapítulo (la portería para Serra), pieza que llamó su atención por lo curioso y caprichoso de su disposición: "Es un paralelogramo, de la mitad de cuyos ángulos arrancan cuatro arcos, que vienen a posar en una sola columna, colocada en el centro. Pero esta columna

60 En Villafranca, Luis de, Misceláneas históricas relativas a cosas de Mallorca, Mss., Palma, Biblioteca Vivot, 1809, vol. II, págs. 305-35.

6. Jovellanos, G.M. de, Obras publicadas e inéditas de... Ob. cit., vol., XLVI, págs. 430-1. 


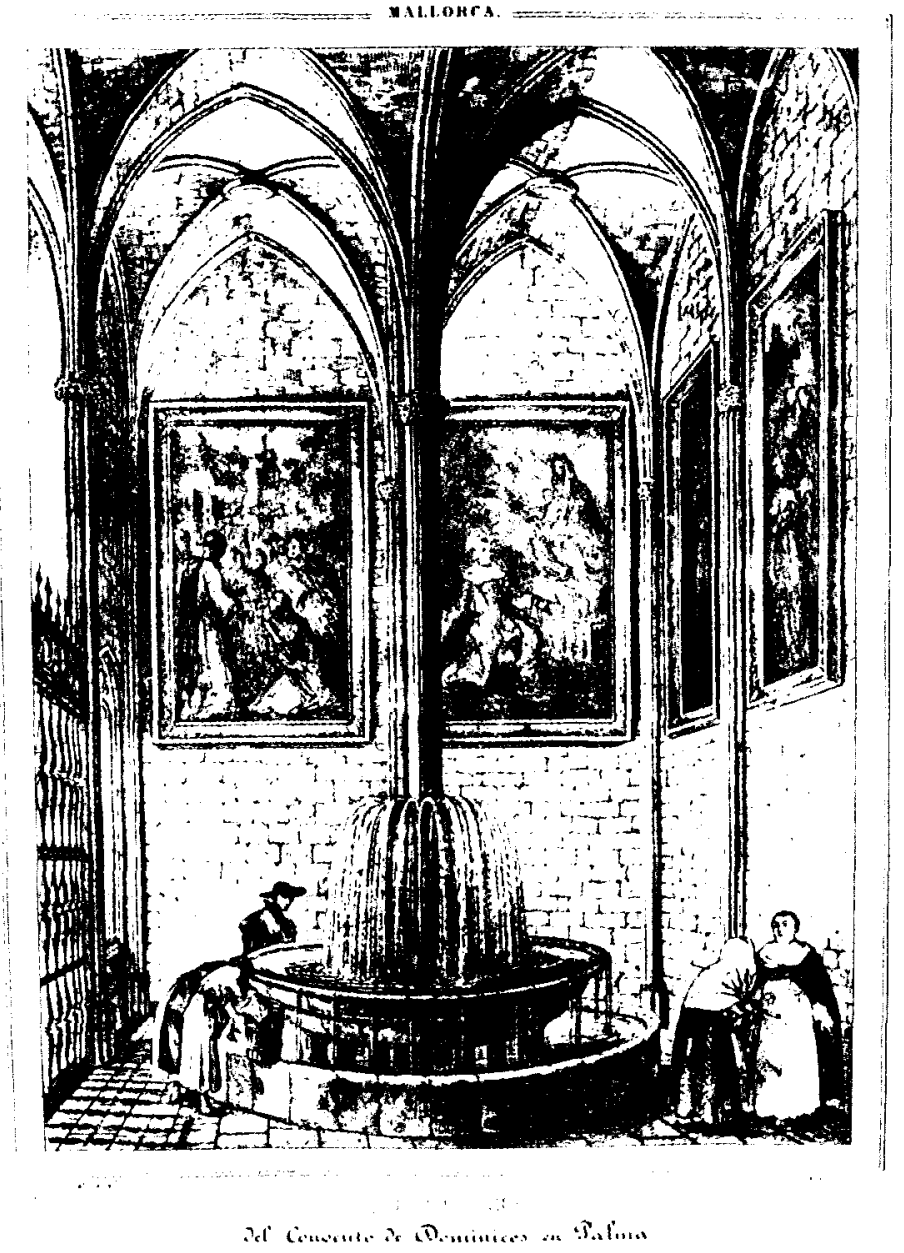

Fig. 7. Porteria del Convento de Dominicos en Palma. Dibujo y litografía de F. J. Parcerisa. En Piferrer, Pablo, Recuerdos y bellezas de España. Mallorca. Barcelona 1842. 
se apoya sobre una tabla o mesa redonda de piedra, que está al ras del plano, y sube de una especie de pozo abierto en él. Esta base o mesa carga en unos cuantos pilarcillos, que la sostienen en torno, de forma que la columna cargada de tan enorme peso, parece cargar sobre el vano, aunque en realidad no es así, porque en el centro hay otro pilar o falsa base, que sube del fondo del pozo, perpendicular al fuste de la columna, $y$ es el que verdaderamente la sostiene" ${ }^{62}$.

5. S. Francisco. La edificación de la iglesia se iniciaría en 1281 y en 1317 se estarían levantando claustro e iglesia; apuntó Jovellanos que posiblemente trabajase en su edificación Jaime Fabra, activo en Sto. Domingo. En la segunda mitad del siglo xIV se suprimió el primitivo artesonado de madera por la actual bóveda de piedra.

Desde el punto de vista artístico, Jovellanos destacó en la iglesia el sepulcro del beato Ramón Llull y la portada principal, con esculturas de Francisco de Herrera y estilísticamente situada entre el manierismo y el barroco. Al igual que ocurre con la descripción de Sto. Domingo, aprovechó el autor para criticar las piezas churriguerescas. También llama la atención que Jovellanos no se detuviese en la descripción del claustro gótico del siglo XIV, obra única en su género y muy elogiada por los autores del romanticismo.

Si del exterior de la iglesia elogió el autor los grandes estribos y la altura de su bóveda, góticos, de su interior destacó la capilla de la Virgen María, donde se hallaba el sepulcro de Llull. Dijo Jovellanos que esta capilla fue construida en 1448. De la compleja iconografía del sepulcro remitió al libro de Custurer ${ }^{63}$, que incluía una calcografía del mismo firmada por Francisco Rosselló.

Siguiendo a Custurer apuntó que la traza de la capilla y el sepulcro eran del lulista Juan Llobet, que dejó acabado el primer cuerpo salvo las estatuas que faltan. En 1487 los jurados ordenaron acabar el sepulcro, construyendo la urna de alabastro y el nicho para la urna, confiando la urna a Francisco Sagrera y la arquitectura a Juan Vicens, que hizo el ático - segundo cuerpo, "nicho bastante alto y fondo, cubierto con una graciosa bovedita formada por cuatro arcos, que partiendo de sus ángulos suben a unirse en una sola clave, según el gusto ultramarino. Al exterior, que tiene la forma de una alta portada, cubren como cinco partes de sus jambas, unas pilastras con cuatro pequeños nichos, abiertos en el frente

52 Jovellanos, G.M. de, Obras publicadas e inéditas de... Ob. cit., vol. XLVI, pág. 431.

6. Custurer, Jaime, Disertaciones históricas del culto inmemorial del Beato Raj'mundo LuIIio. Mallorca, Imp. Miguel Capó, 1700. 


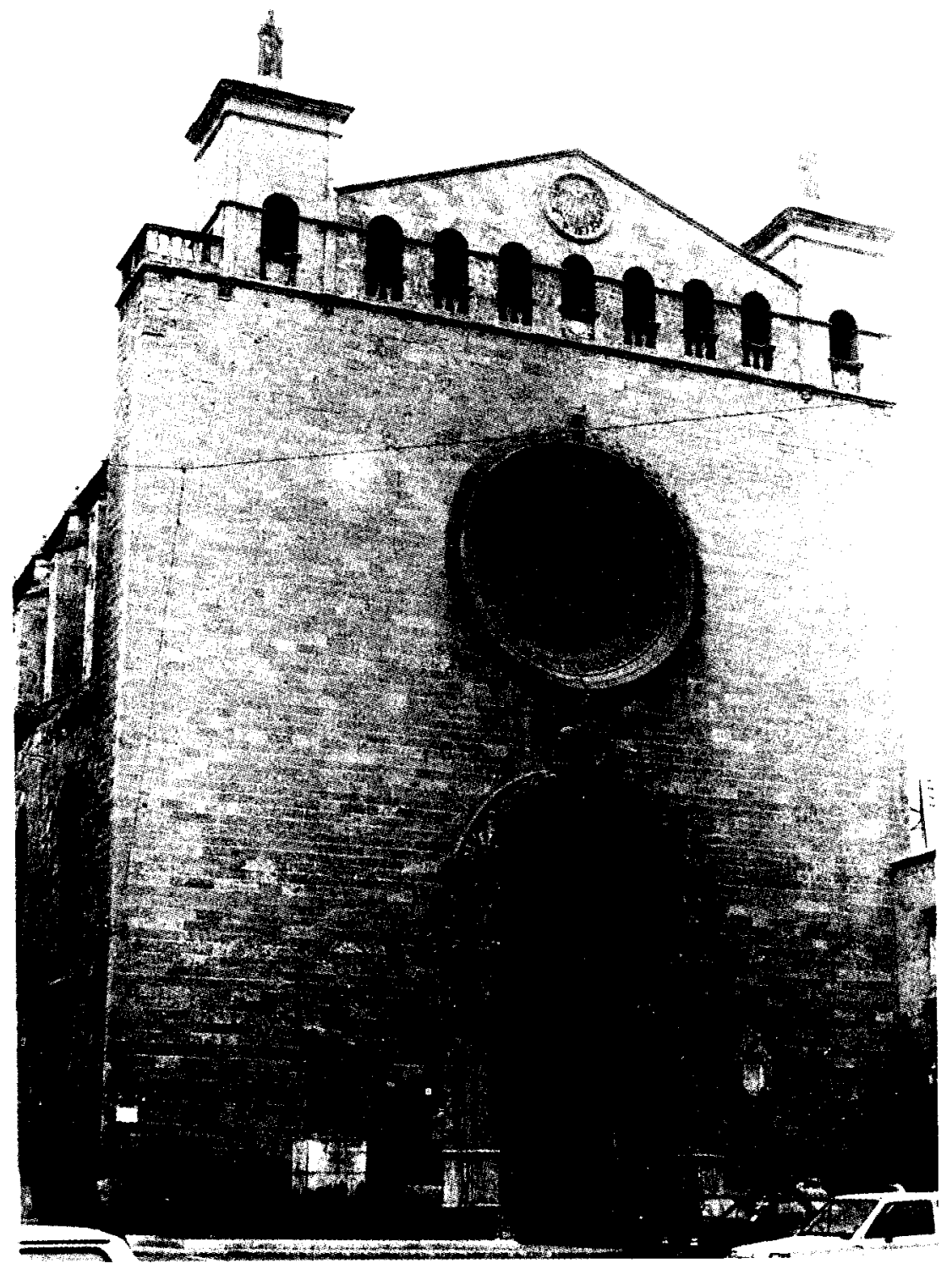

Fig. 8 Fachada de la iglesia de S. Francisco. 
de cada una, como para colocar ocho estatuillas, y sobre cuyo capitel están dos animaluchos. A la espalda se descubre el arco... que remata en una pirámide cortada en su apéndice, que tendrá de alto dos palmos" ${ }^{64}$.

Del frontis de la iglesia señaló que el primitivo gótico fue arruinado por un rayo en 1480 (sic) ${ }^{65}$, construyéndose el nuevo en 1621 . Pero lo que más atrajo su interés fue la portada Principal, de finales del siglo XVII. Dijo que era:

"obra grande y majestuosa por su altura y ornatos de no mal gusto de arquitectura, aunque afeada con algunos colgajos y moños, pero de muy buena escultura, pues se ven en ella cuatro grandes estatuas, la de S. Jorge en lo más alto del arco exterior, la de la Virgen Inmaculada sobre la columna o pilastra que divide las dos puertas contenidas en él, y abajo, al uno y otro lado, las de S. Francisco, y el sutil Escoto (sic): todo ello trabajado con mucha diligencia y buen gusto en la hermosa piedra de Santañí» ${ }^{66}$

Jovellanos atribuyó a Francisco de Herrera la autoría de la portada ${ }^{67}$. En la descripción y crítica del interior siguió a Serra y sus Varias noticias relativas a Mallorca..., mencionando el retablo Mayor, con la estatua principal del santo patriarca de Jaime Blanquer, la de S. Jorge, de Gabriel Coll, y las realizadas por Jerónimo de Berard. Las críticas a las piezas churriguerescas aparecen al referirse a la capilla del beato Ramón Llull, de cuyo retablo señaló que:

"pudo merecer sus elogios en el tiempo en que fue construido; pero sus columnas espirales del segundo cuerpo, su cornisamento, interrumpido con entradas y salidas, sus conchas y adornos caprichosos de tarjetones y otras zarandajas, que anuncian ya la decadencia de la escultura y arquitectura de retablos hacia el gusto riberesco, no pueden merecerlos en nuestra época» ${ }^{68}$.

Reafirmándose en las críticas de Serra a las reformas de su interior, añadió Jovellanos que «tiene mucha razón, si como creo alude a un gran

64 Jovellanos, G.M. de, Obras publicadas e inéditas de... Ob. cit., vol. XLVI, págs. 434-5.

65 Fue en 1580.

66 Jove!lanos, G.M. de, Ibidem. Jovellanos confunde la estatua de Sto. Domingo, que está abajo, con la de Duns Scoto. La de éste último y la de Llull están en el segundo cuerpo, flanqueando la de la Virgen.

67 En realidad Herrera sólo la debió terminar entre 1697 y 1700 . Parece que desde 1699 ya estaba concluida la construcción del portal, y trabajarían en él otros escultores.

ki Jovellanos, G.M. de, Obras publicadas e inéditas de... Ob. cit., vol. XLVI, pág. 437. 


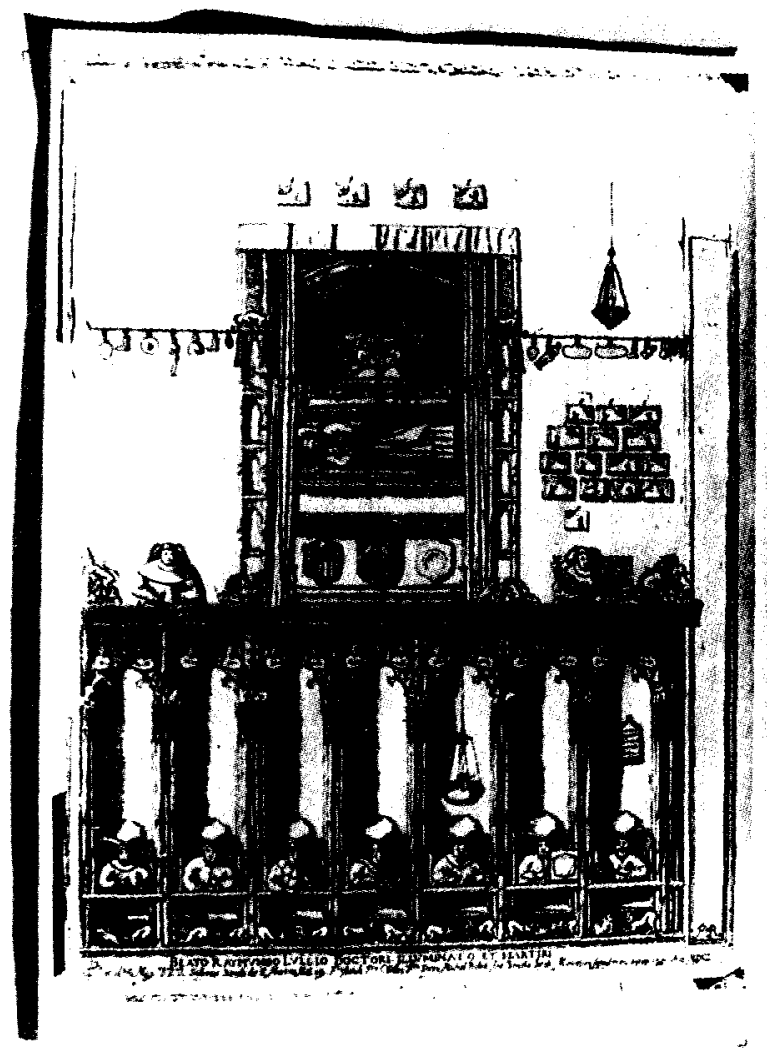

Fig. 9 Sepulcro de Raimundo Lulio. Calcografia de Francisco Rosselló. En Custurer, Jaime, Disertaciones históricas del culto inmemorial del Beato Raymundo Lullio. Mallorca 1700.

zócalo de mármoles que se sobrepuso por todo el interior del templo hacia la mitad del siglo pasado, sobre el cual se levantan entre los arcos de las capillas ciertos pilastrones de madera estriados y marmoleados al gusto moderno, y sin razón ni oficio alguno conocido; pues que nada carga sobre ellos, ni siquiera igualan en altura a los ya dichos arcos. $Y$ si a esta deformación añade Usted un blanqueo con fajas de pinturas y colorines, con que se van embadurnando actualmente todas las paredes 


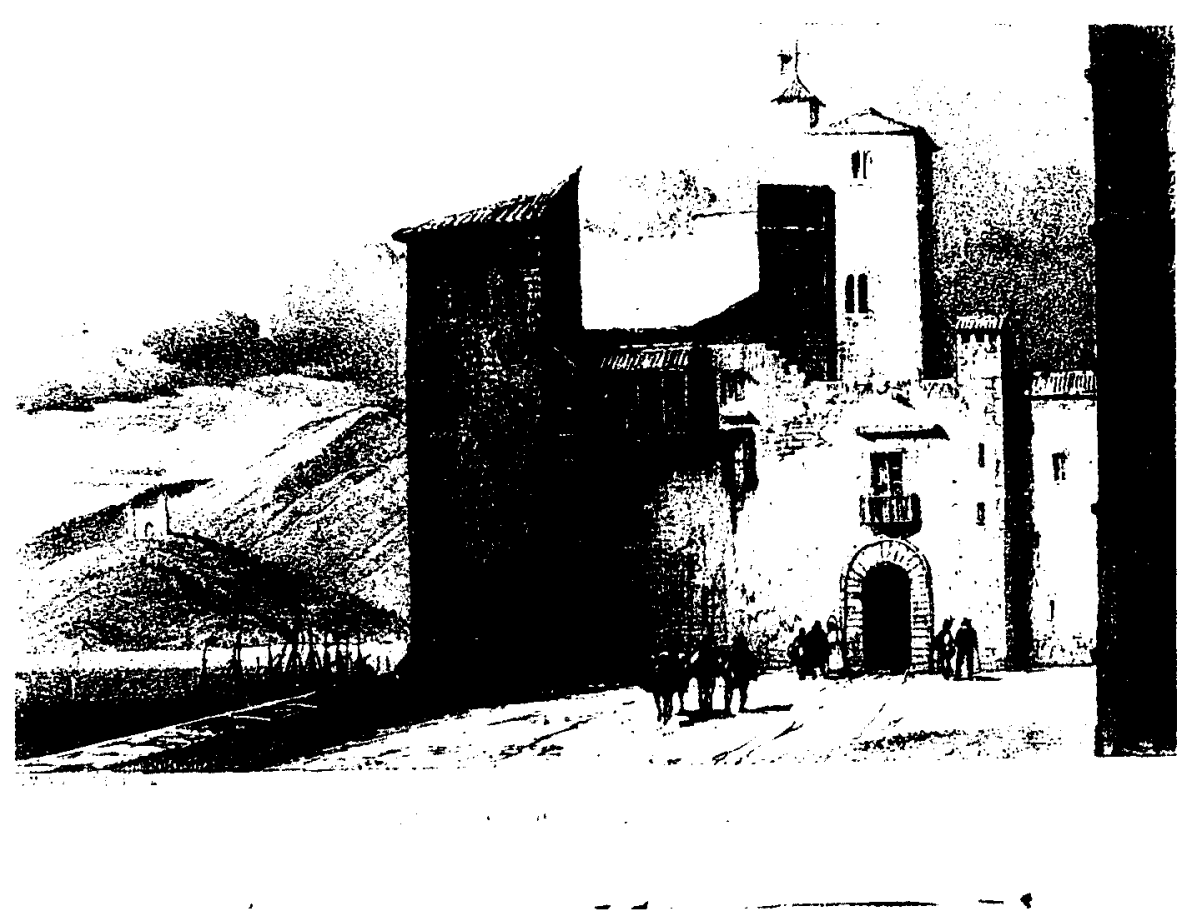

Fig. 10. Convento antiguo junto a la Catedral (Palacio de la Almudaina). Dibujo de E.M.G., litografía de C. Hague. En Grosvenor, E.M., Narrative of a yacht voyage in the Mediterranean... London 1842.

y bóvedas de este hermoso templo, hallará que nada han dejado de hacer los frailes modernos para desterrar de él su venerable antigua forma” ${ }^{69}$.

6. Otros edificios. En su Descripción Panorámica desde el Castillo de Bellver y en su Diario decimotercero habla también de otras construcciones menos importantes.

En éste último hizo breves comentarios de algunos conventos e iglesias, como de la de Sta. Eulalia (siglos XIII-XVI) de estilo gótico: "Comparable con una catedral, las columnas de dos claves son octogonales y lisas las restantes: se ven estriadas porque los canales que hay en el frente y costados de los arcos que cargan en ellas bajan por las faces del fuste hasta su pie... Las naves laterales corren por detrás del Presbiterio con sus capillas» ${ }^{70}$.

69 Jovellanos, G.M. de, Obras publicadas e inéditas de.. Ob. cit., vol. XLVI, pég. 436

ro Jovellanos, G.M. de, Obras publicadas e inéditas de... Ob. cit., vol. LXXXVI, págs. 142-3. 


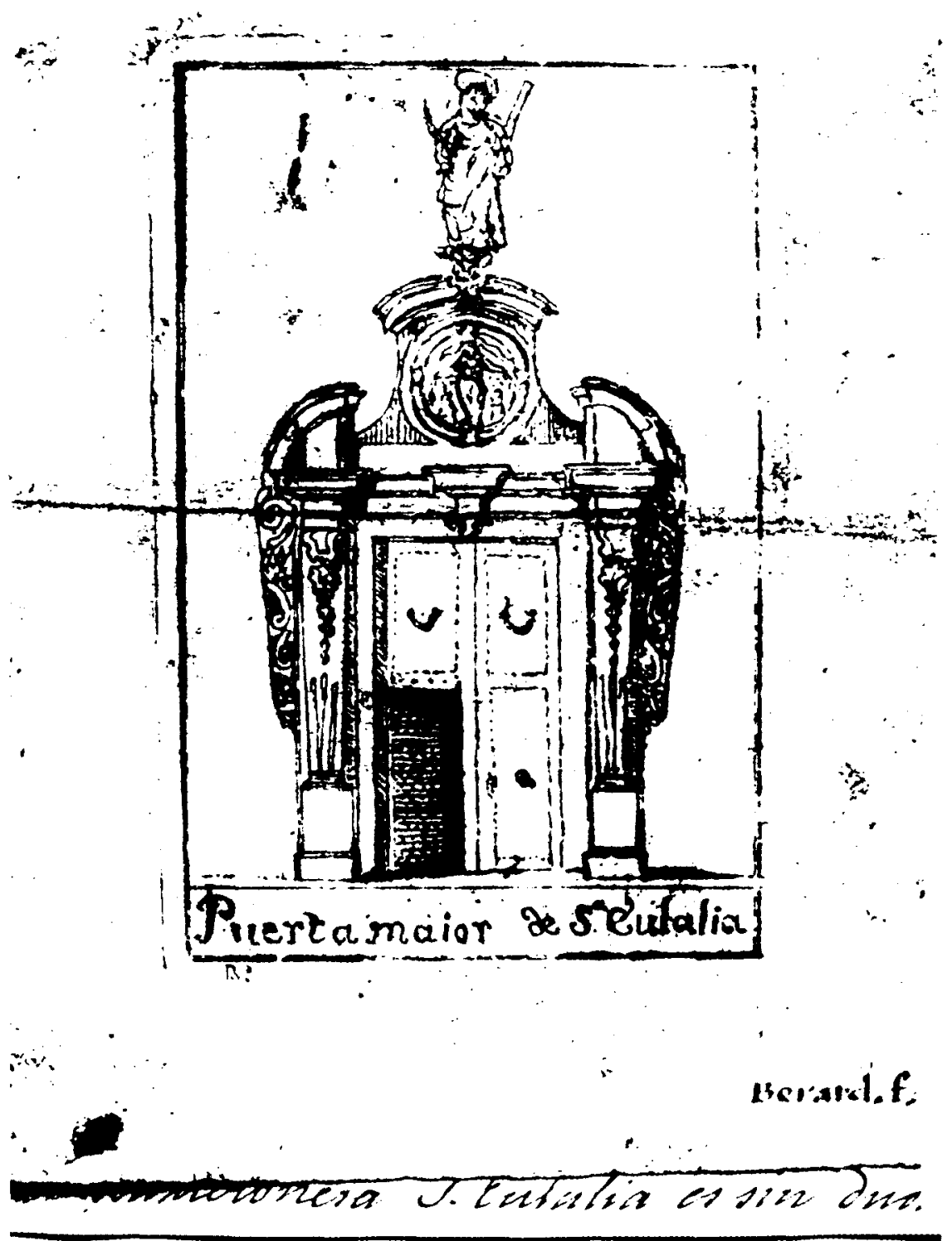

Fig. 11. Puerta mayor de Sta. Eulalia. Calcografía de Jerónimo Berard (finales del siglo XVIII). En BOVER, Joaquín M, ${ }^{a}$, Misceláneas históricas mallorquinas. Mss., t. V, fol. 57. Palma, Biblioteca March. Reproduce el antiguo portal Mayor obra de Jaime Blanquer (1621), de transición manierismo-barroco. La fachada fue reformada en estilo neogótico por Juan Miguel Sureda (1892-1924). 
En la iglesia de Montesión (siglos XVI-XVII) se mostró crítico con su decoración barroca, y decía que estaba "afeada con garambainas modernas, ...En el Presbiterio (lado del Evangelio) magnífico sepulcro del Bailío Veri, de mármoles, con estatua encima, ...Sospéchole de la entrada del XVIII, ${ }^{71}$.

De la dieciochesca iglesia de Sta. Magdalena destacó la capilla y sepulcro de la beata Catalina Thomás, obra de principios del siglo xIx costeada por el cardenal Despuig ${ }^{72}$ y de líneas neoclásicas, estilo que el cardenal difundió por la isla.

Sobre otras construcciones civiles y militares de Palma, de su Descripción Panorámica, habló Jovellanos sobre el Palacio de la Almudaina, coincidiendo con la opinión de otros autores en su falta de unidad estilística y regularidad. Antiguo alcázar musulmán, indicó que fue reformado por Jaime II para residencia real, y que algunos lo creían construido en tiempos de los romanos. Fue objeto de sucesivas remodelaciones a lo largo de su historia, "de tal manera que nada ofrece de regular ni de noble en su forma. En medio de las obras modernas se descubren aún cuatro de las viejas torres, altas, estrechas y cuadradas, entre las cuales, y a su espalda descuella la famosa torre del Angel, llamada así por la estatua de bronce que tienen encima, y que dicen está rebajada a la mitad de altura que tuvo cuando era homenaje de la antigua fortaleza» ${ }^{73}$.

Consideró las murallas de la ciudad inexpugnables, al igual que Dameto y Serra. "Su fortificación, que la hace a un mismo tiempo hermosa y terrible, es de las más respetables de España por la altura, extensión y robustez de sus muros, y por la muchedumbre de obras y defensas avanzadas que la protegen" ${ }^{74}$.

Dedicó un espacio Jovellanos para describir el conjunto del antiguo puerto de Palma, Porto-Pi, del que destacó las dos torres del siglo xIII. De la Torre de Lamparón (Porto-Pi), usada como faro, dijo que era «un bello edificio de tres cuerpos: los dos cuadrados y sin más adornos que los grandes modillones, que se avanzan a sostener el antepecho del primero y forman sus ladroneras del puro gusto arabesco. El tercer

Jovellanos, G.M. de, Obras publicadas e inéditas de... Ob. cit, vol. LXXXVI, pág. 142.

Representante de la ilustración en la isla, fundó en su villa de Raxa un museo de esculturas y objetos grecorromanos. Ver SalvA, Jaime, El Cardenal Despuig. Palma, Imp. Alcover, 1964.

JovelLanos, G.M. de, Obras publicadas e inéditas de... Ob. cit., vol. LXXXVII, págs. 361-2. JovelLanos, G.M. de, Obras publicadas e inéditas de... Ob. cit., vol. LXXXVII, pág. 359. El proyecto de las murallas fue obras del italiano Jacobo Fratin (1575), alargándose su construcción durante los dos siglos siguientes. 


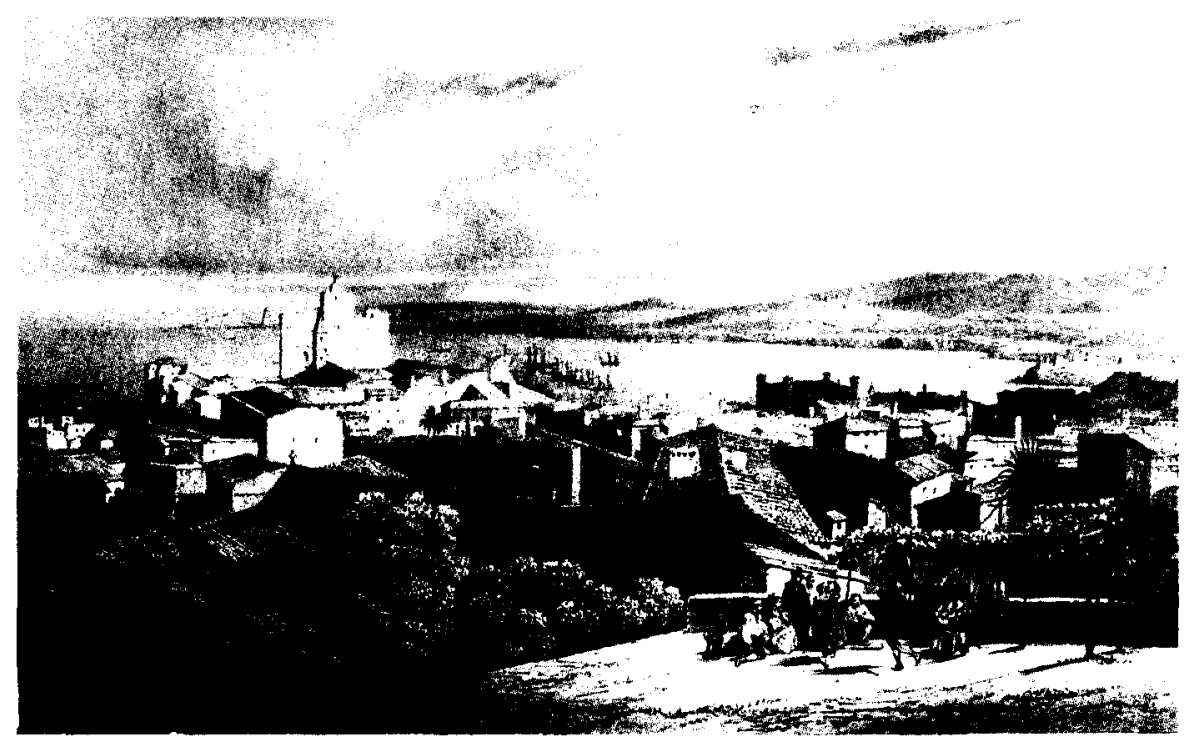

Fig. 12. Palma, isla de Mallorca. Dibujo de Girault de Prangey, litografía de Bichebois, figuras de Bayot. En Vistas de España. París 1849.

cuerpo aparece octágono... Encima se levanta la hermosa linterna, que es también octágona... forma como un cuarto cuerpo, y da al edificio la más gallarda apariencia» ${ }^{75}$.

También describió la Torre de Pelaires. «Es cuadrada también, pero de un solo cuerpo, y adornada en lo alto con almanques, que en forma de modillones la coronan sosteniendo su antepecho avanzado, y formando ladroneras en sus claros, cosa que indica igualmente el gusto de la arquitectura arabesca»" ${ }^{76}$. Citó el autor el Castillo de S. Carlos, "obra moderna y por su fuerza muy respeable, que a la entrada del siglo xvII, empezó... el virrey don Carlos Colona» ${ }^{77}$.

75 Jovellanos, G.M. de, Obras publicadas e inéditas de... Ob. cit., vol. LXXXVII. pág. 355. Se construyó en el siglo XIII, aumentando en un segundo cuerpo en el xiv y con un tercero a principios del XvII.

76 Jovellanos, G.M. de, Obras publicadas e inéditas de... Ob. cit., vol., LXXXVII, pág. 356. Esta otra torre data también del siglo XIII y fue usada como torre de señales. Desde 1475 se usó con fines sanitarios para cuarentenas, hasta el primer cuarto del siglo xvII, volviéndose a utilizar con fines defensivos desde esta fecha.

7 Jovellanos, G.M. de, Obras publicadas e inéditas de... Ob. cit., vol. LXXXVII, pág. 3545. La obra es de 1612, ampliada por Vicente Mut en 1663. 


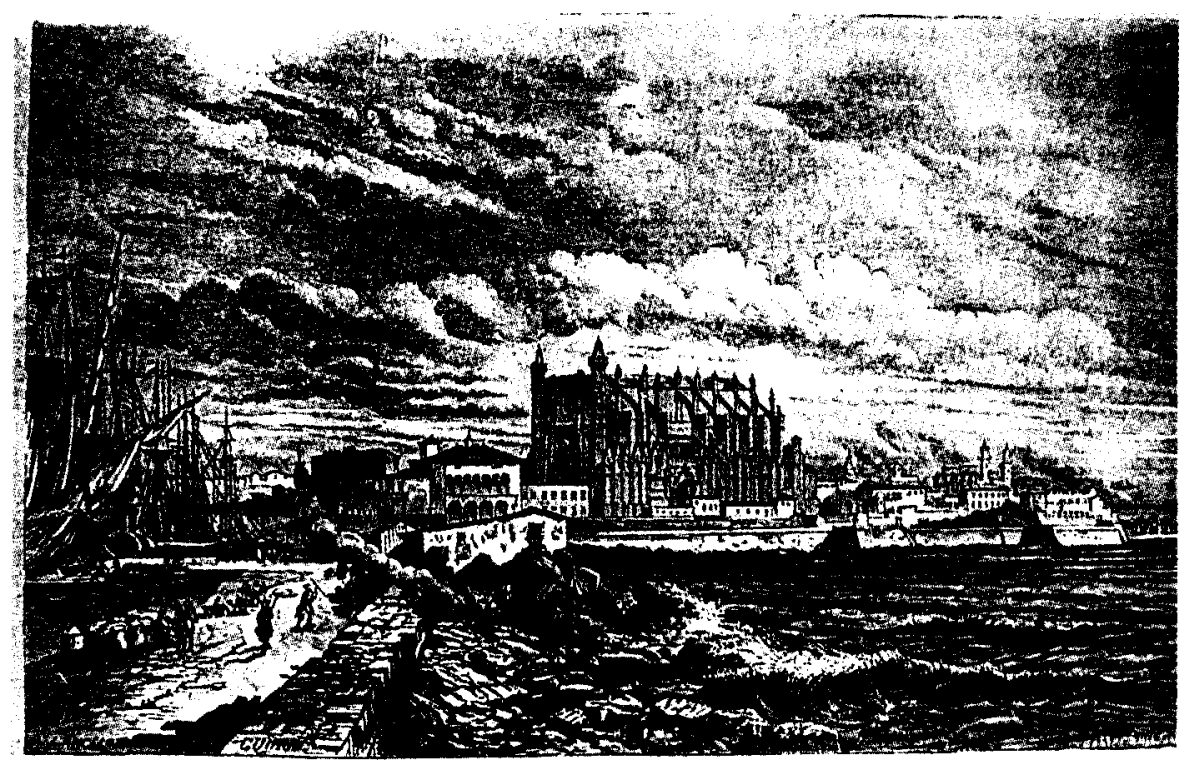

VISTA DE I'ALSA DE MALLUKCA

Fig. 13. Vista de Palma de Mallorca. Xilografía de Lancelot, Guiaud, Cosson y Smeeton. Mediados del siglo Xix.

Finalmente, y al igual que otros viajeros que llegaban a la bahía de Palma, Jovellanos destacó la bella vista que ésta ofrecía, con sus murallas y sus magníficos edificios descollando sobre ella; algo que también entusiasmó a los viajeros del romanticismo:

"La insigne ciudad de Palma, asentada a su orilla y en el centro de tan grandes objetos, se alza orgullosa para dominarlos, y para completar y ennoblecer el magnífico cuadro, que reúne cuanto hay de más bello en la naturaleza hermoseada por el arte" ${ }^{78}$.

\section{LA INFLUENCIA DE JOVELLANOS EN LOS AUTORES DEL ROMANTICISMO}

Las cartas de Jovellanos sobre la arquitectura gótica de Palma, que significaron la reivindicación de aquella y del gótico en general, tuvieron

78 Jovellanos, G.M. de, Obras publicadas e inéditas de... Ob. cit., vol. LXXXVII, pág. 344. 


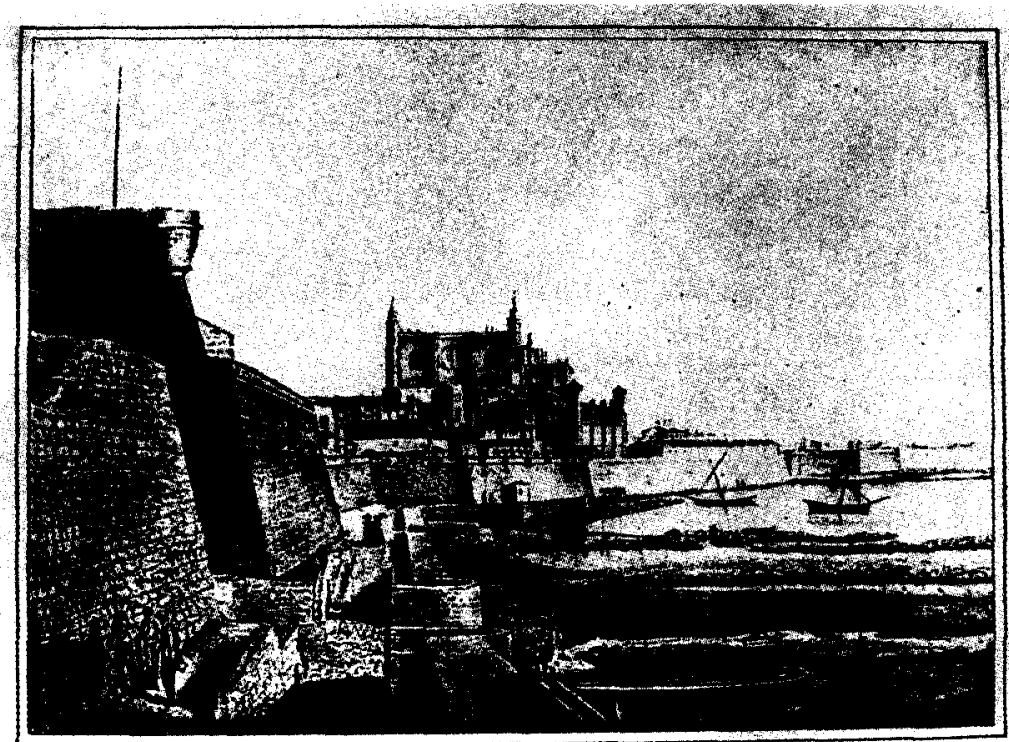

IPAILMRA VISTA IDIER WADDO IDTHL ORSTIE

Fig. 14. Palma vista del lado del oeste. Litografia de Francisco Muntaner. En Furio, Antonio, Panorama óptico-histórico-artístico de las Islas Baleares. Palma 1840.

gran influencia en autores ilustrados posteriores como Ceán Bermúdez o Jaime Villanueva (1765-1824) ${ }^{79}$, que escribieron sobre aquella. Pero, sobre todo, fueron los autores de la etapa romántica, seducidos por la historia y el arte medievales, los que se sintieron más atraidos por ellas, viendo en Jovellanos a su más esclarecido precedente en el “descubrimiento" de la arquitectura gótica insular. Eruditos locales como Furio y Bover, viajeros nacionales como Piferrer y Juan Cortada (1805-68) y extranjeros como Joseph Bonaventure Laurens (1801-90) y George Sand (1804-76) supieron apreciar en las cartas de Jovellanos una nueva sensibilidad artística y literaria que anunciaba la que se impuso en torno a 1840 en Mallorca, con la difusión del romanticismo.

79 Villanueva, J., Viaje iiterario... Ob. cit., vols. XXI y XXII; Llaguno, Eugenio y CeÁn BerMúdez, Juan Agustín, Noticias de los arquitectos y arquitectura de España... Madrid, Imp. Real, 1829 , vols. I. 
Los autores de esta etapa se guiaron por las cartas de Jovellanos en sus apreciaciones sobre estos edificios góticos tratados por el gijonés, considerados los mejores y más representativos. La figura de Jovellanos fue considerada por los autores españoles del romanticismo como la del gran precursor del interés por la historia y el arte medievales de Mallorca, y sobre todo por ser el iniciador del gusto por la arquitectura gótica, a través de los edificios de Palma.

El erudito mallorquín Antonio Furió recordó en su Panorama... como Jovellanos se sintió atraído por los señeros edificios góticos de Palma, que "merecen la primacia entre nuestros mejores monumentos de las artes: ellos han llamado sobremanera la atención de los sabios y estudiosos que han visitado esta tierra, no siendo el menor de ellos el incomparable... Jovellanos" ${ }^{80}$.

En su descripción de la Lonja, Furió tomó los datos históricos de Jovellanos, repitiendo sus mismos elogios. También causó gran impresión en Furió, la Descripción histórico-artística del Castillo de Bellver de Jovellanos, rememorando en su descripción del Castillo la prisión de aquel y sus poéticas evocaciones medievales.

Al hablar de los conventos de Sto. Domingo y de S. Francisco, Furió copió la Memoria sobre las fábricas de los conventos de Sto. Domingo y $S$. Francisco de Palma, y señaló al referirse a Sto. Domingo, que "habiendo el Sr. Jovellanos descrito su magnífico templo y demás oficinas de mérito que se veían en él, debemos enmudecer a la presencia de tan ilustre cronista y copiar como lo hacemos su carta histórica sobre el demolido edificio" ${ }^{81}$.

Otro erudito local, Joaquín M. ${ }^{a}$ Bover, manifestó similar opinión. Respecto a la Lonja, copió lo escrito por Jovellanos sobre aquel edificio en su Descripción Panorámica; "no nos detendremos aquí a hacer una reseña de este suntuoso edificio, por ser asunto que ha evacuado completamente el sapientísimo... Jovellanos» ${ }^{82}$.

ao Furió y SAStre, Antonio, Panorama óptico-histórico-artístico de las Islas Baleares. Palma, Imp. P. J. Gelabert, 1840 (a nuestros lectores).

81 Furió y SAStre, A., Panorama óptico... Ob. cit., pág. 51. Respecto a S. Francisco escribió Furió sobre las investigaciones de Jovellanos, y recalcó que ueste ilustrado patriota no dejó resorte alguno para aclarar los hechos históricos", pág. 58.

92 En el vol. Il (notas de Bover y Moragues) de la Historia general del Reino de Mallorca, de Juan Dameto, Vicente Mut y Gerónimo Alemany, 2. ${ }^{a}$ ed. Palma, Imp. Nal. a cargo de Juan Guasp y Pascual, 1840-1, pág. 597. Bover publicó por vez primera esta carta en su Diccionario histórico-greográfico-estadístico... Ob. cit., en 1843. 
También recordó la Descripción histórico-artística del Castillo de Bellver y su Apéndice primero al hablar de este monumento. "Como dice el sabio Jovellanos, uno de los mejores monumentos militares del siglo xIII (sic), levantado con tino y maestría... En Bellver sufrió con constancia su persecución el sapientísimo Jovellanos" ${ }^{83}$. Como Furió, Bover copió la Memoria sobre las fábricas de los conventos de Sto. Domingo y S. Francisco de Palma, y refiriéndose al demolido convento de dominicos apuntó que «fue uno de los monumentos que dió vastísimo campo al inteligente, concienzudo y elegante literato... Jovellanos para escribir una memoria llena de erudición" ${ }^{84}$.

En sus comentarios sobre la Catedral, Bover transcribió lo escrito por Piferrer para el volumen mallorquín de los Recuerdos y bellezas de España. Siguió el criterio de Piferrer, que llamó la atención del error en la lectura de los libros de cuentas catedralicios por parte de Jovellanos. Bover disculpó el error de Jovellanos, "pues escribía en su prisión y sobre los datos que otros le enviaban" ${ }^{85}$.

El catalán Pablo Piferrer, uno de los más fervientes apologistas de la arquitectura medieval y del estilo gótico, también valoró en mucho las cartas de Jovellanos y apreció su talante claramente prerromántico, en todo lo que suponía de anticipación a los fenómenos del historicismo, medievalismo y nacionalismo propios de la etapa romántica. "Un solo español, desde el claustro silencioso o desde el sombrío castillo..., alzó el primero una punta del velo que cubría los monumentos de la isla. Hombre educado en el rigor de la escuela antigua, no vaciló en evocar las sombras graciosas y esbeltas de la edad media; y dotado de un gusto exquisito y de saber profundo en las bellas artes, tan seguros y sólidos pasos dió por aquel nuevo sendero, que si alguno osó recorrerlo después, anduvo sobre sus antiguas huellas» ${ }^{86}$.

Comparables fueron los criterios sobre las carta de Jovellanos de otro escritor catalán del romanticismo, Juan Cortada, que viajó a Mallorca poco después de Piferrer.

83 Dameto, J.; Mut, V.; Alemany, G., Historia general... Ob. cit, vol. II, págs. 564-5. El edificio es de principios del siglo XiV.

84 Dameto, J.; Mut, V.; Alemany, G.; Historia general... Ob. cit., vol. H, pág. 1018. También copió lo referente a S. Francisco, pues ambos conventos «ocuparon la pluma del Sr. Jovellanos, cuyos juicios nos complacemos en exponer", pág. 1053.

85 Dameto, J.; Mut, V.; Alemany, G., Historia general... Ob. cit., vol. II, pág. 939. Se refiere a la supuesta carta de Jovellanos, que Somoza atribuyó a Barberí.

${ }^{86}$ Piferrer, Pablo, Recuerdos y bellezas de España. Mallorca. Barcelona, J. Verdaguer, 1842, pág. 2. 
Siguió la Descripción histórico-artística de la Lonja de Palma del gijonés al hablar de ese edificio ${ }^{87}$. Igual que Piferrer, Cortada sintió una gran admiración por la Descripción histórico-artística del Castillo de Bellver de Jovellanos, conmoviéndose al visitar su celda ${ }^{88}$.

Fuera de España, la figura de Jovellanos y sus cartas fueron menos conocidas. El francés Laurens, que fue junto con Piferrer uno de los principales difusores de los méritos de la arquitectura gótica de Palma, también reconoció el mérito de los trabajos del gijonés, leyéndolos más críticamente que los españoles. De la Lonja de Palma, dijo que "Jovellanos le consagró una extensa carta llena de erudición, en la cual acompañan a la historia del monumento ciertos pormenores que, si bien carecen de interés para los extranjeros, son de mucha importancia para las personas del país» ${ }^{89}$.

También recordó la prisión del erudito gijonés en el Castillo de Bellver, y su Descripción histórico-artística del mismo ${ }^{90}$. Utilizó la supuesta carta de Jovellanos sobre la Catedral, la resumió e incluyó algunos fragmentos en sus descripciones del edificio: "la carta de Jovellanos contiene una multitud de datos y de hechos curiosos sacados de buenas e incontestables fuentes, puesto que la mayor parte se confirman por la obra del arquitecto" ${ }^{91}$.

George Sand opinó como Laurens al referirse a las cartas de Jovellanos. Sobre su Descripción histórico-artística de Bellver, apuntó que «ocupó sus tristes ocios describiendo científicamente su prisión y trazando la historia de los acontecimientos trágicos de que habia sido teatro en tiempo

${ }_{87}$ Contada, Juan, Viaje a la isla de Mallorca en el estio de 1845. Barcelona, A. Brusi, 1845, págs. $62-6$

${ }_{88}$ Cortada, J. Viaje a la isla de Mallorca... Ob. cit., págs. 205-6.

89 LAURENS, Joseph Bonaventure, Recuerdos de un viaje artístico a la isla de Mallorca. Palma, Ed. Ayer, 1971, pág. 50. La edición francesa es de 1840, Montpellier, Boehm et Cie.

9o LaURenS, J. B., Recuerdos de un viaje artístico... Ob. cit., pág. 71

91 Laurens, J. B., Recuerdos de un viaje artístico... Ob. cit., pág. 36. Sin embargo Laurens criticó algunas de las afirmaciones de la carta y el propio rigor científico de los eruditos locales Furió y Bover. "Es sensible que estos anticuarios no hayan tenido conocimiento más que de papales viejos y antiguas tradiciones, y que hayan permanecido indiferentes para con los es. tudios monumentales hechos de veinte años a esta parte en Francia e Inglaterra". Ibidem, Laurens criticaba que tanto la capilla Real como el antiguo altar Mayor gótico fuesen considerados obras del siglo xill. 
de las guerras de la Edad Media» ${ }^{92}$, y también destacó las cartas sobre la Catedral y la Lonja: “los mallorquines deben también a su permanencia en la isla una excelente descripción de su Catedral y de su Lonja. En una palabra, sus escritos sobre Mallorca son los mejores documentos que puedan ser consultados" ${ }^{93}$.

92 SAND, George, Un invierno en Mallorca. Barcelona, Orbis, 1989, pág. 74. La edición francesa es de 1842.

93 SAND, George, Ibidem. Hace referencia a la carta de la Catedal atribuida a Jovellanos por Furió. 